\title{
Stability and Hydrolyzation of Metal Organic Frameworks with Paddle-Wheel SBUs upon Hydration
}

\author{
Kui Tan, ${ }^{\dagger}$ Nour Nijem, ${ }^{\dagger}$ Pieremanuele Canepa, ${ }^{\ddagger}$ Qihan Gong, ${ }^{\S}$ Jing Li, ${ }^{\S}$ Timo Thonhauser ${ }^{\ddagger}$ and Yves J \\ Chabal* $^{\dagger}$ \\ ${ }^{\dagger}$ Department of Materials Science \& Engineering, University of Texas at Dallas, Richardson, Texas 75080 \\ "Department of Physics, Wake Forest University, Wake Forest Road, Winston-Salem, North Carolina, 27109 \\ ${ }^{\S}$ Department of Physics and Astronomy and Department of Chemistry and Chemical Biology, Rutgers University, 610 Taylor \\ Road, Piscataway, New Jersey 08854
}

KEYWORDS. Metal organic frameworks, paddle wheel, secondary building units, hydration, in situ IR spectroscopy, Raman, X-ray diffraction

Supporting Information

\begin{abstract}
Instability of most prototypical metal organic frameworks (MOFs) in the presence of moisture is always a limitation for industrial scale development. In this work, we examine the dissociation mechanism of microporous paddle wheel frameworks $\mathrm{M}(\mathrm{bdc})(\mathrm{ted})_{0.5}[\mathrm{M}=\mathrm{Cu}, \mathrm{Zn}, \mathrm{Ni}, \mathrm{Co}$; bdc= 1,4-benzenedicarboxylate; ted= triethylenediamine $]$ in controlled humidity environments. Combined in-situ IR spectroscopy, Raman, and Powder x-ray diffraction measurements show that the stability and modification of isostructual $\mathrm{M}(\mathrm{bdc})(\mathrm{ted})_{0.5}$ compounds upon exposure to water vapor critically depend on the central metal ion. A hydrolysis reaction of water molecules with $\mathrm{Cu}-\mathrm{O}-\mathrm{C}$ is observed in the case of $\mathrm{Cu}(\mathrm{bdc})(\mathrm{ted})_{0.5}$. Displacement reactions of ted linkers by water molecules are identified with $\mathrm{Zn}(\mathrm{bdc})(\text { ted })_{0.5}$ and $\mathrm{Co}(\mathrm{bdc})(\text { ted })_{0.5}$. In contrast, $\mathrm{Ni}(\mathrm{bdc})(\mathrm{ted})_{0.5}$ is less susceptible to reaction with water vapors than the other three compounds. In addition, the condensation of water vapors into the framework is necessary to initiate the dissociation reaction. These findings, supported by supported by first principles theoretical van der Waals density functional (vdW-DF) calculations of overall reaction enthalpies, provide the necessary information for determining operation conditions of this class of MOFs with paddle wheel secondary building units and guidance for developing more robust units.
\end{abstract}

\section{Introduction}

Metal organic frameworks (MOFs) are a family of nanoporous materials that are attracting great interest as a potential material for gas storage and separation. ${ }^{1,2}$ These relatively new porous materials result from the reaction between organic and inorganic species that can assemble into one-, two- or threedimensional structures. ${ }^{3}$ The two subunits within the structure contains inorganic coupling parts, also referred to secondary building units (SBUs), and organic linkers, such as dicarboxylate or other organic rings. ${ }^{4} \mathrm{~A}$ great variety of cations can be incorporated into the framework and a wide choice of functionalized organic linkers provide many possibilities to design the structures and tune the properties of the final porous materials. ${ }^{5,6}$

The high surface areas, porosity and tunable structures make this type of materials very promising for a variety of applications including gas storage, separation, sensing, catalysis and drug delivery. ${ }^{3,7-16}$ Efforts have been done to explore MOFs as a sorbent for $\mathrm{H}_{2}$ storage and $\mathrm{CO}_{2}$ capture materials. $\mathrm{H}_{2}$ storage in MOFs materials is usually achieved thorough fast physical adsorption onto the surface of pores with a large adsorption capacity. ${ }^{16} \mathrm{MOF}$ are also viewed as an ideal platform for next generation $\mathrm{CO}_{2}$ capture materials owing to its large adsorption capacity and chemical tunability of the interaction between $\mathrm{CO}_{2}$ and adsorbents. ${ }^{15}$ Despite these interesting applications, these studies have pointed out some issues that must be evaluated and addressed before MOFs is used in real-world systems. One of the major concern for using MOFs in gas storage and separation is their chemical stability under humid condition. ${ }^{15,16}$ The stability of MOFs under water vapor atmosphere has so far been mainly evaluated by X-ray Diffraction. ${ }^{17-19}$ Some widely investigated MOFs including MOF-5, MOF-177, though exhibiting excellent performance in $\mathrm{H}_{2}$ and $\mathrm{CO}_{2}$ storage in porous materials, are not stable in the presence of small amount of water. ${ }^{20-22}$ Greathouse and Allendorf used empirical force fields and molecular dynamics to simulate the interaction of water with MOF-5. ${ }^{21}$ They predicted that the low stability of MOF-5 in water is due to the weak interaction between $\mathrm{Zn}$ and $\mathrm{O}$ atoms in the structure. This is consistent with the experimental results of Huang, who proposed that water can strongly bind to the framework, leading to hydrolysis and the formation of terephthalic acid. ${ }^{20}$ In other studies, Low modeled the reaction of water with metal organic frameworks from first principles and determined hydrolysis products. ${ }^{18}$ 
While some theoretical work has been done to understand the interaction and possible reaction of water molecules with MOFs, there are no experimental studies to validate these theoretical model and give the detailed information of structural decomposition of metal organic framework. ${ }^{23}$ Precise characterization of reaction of water molecules with frameworks building units such as breaking and reforming bonds is extremely important to obtain insight into the mechanism of MOFs dissociation process in humid environments.

This work focuses on water interaction with one prototypical metal organic framework, $\mathrm{M}(\mathrm{bdc})(\mathrm{ted})_{0.5}[\mathrm{M}=\mathrm{Cu}, \mathrm{Zn}, \mathrm{Ni}, \mathrm{Co}$, $\mathrm{H}_{2}$ bdc $=1$,4-benzenedicarboxylate; ted = triethylenedia mine], that contains SBUs of two 5-coordinate copper cations bridged in a paddle wheel-type configuration. ${ }^{24-31}$ (See Fig. 1 and Fig. S1). $\mathrm{M}(\mathrm{bdc})(\mathrm{ted})_{0.5}$ has been shown to be an excellent absorbent for a variety of gases $\left(\mathrm{H}_{2}, \mathrm{CO}_{2}, \mathrm{CH}_{4}\right.$ and other hydrocarbons). ${ }^{29}$. 31 The paddle wheel binuclear metal clusters within $\mathrm{M}(\mathrm{bdc})(\text { ted })_{0.5}$ can be found in a large number of reported nanoframeworks materials with high microporosity, thermal stability, good sorption properties and other advanced functional properties such as magnetic property. ${ }^{32-37}$ Using new pillaring or mixed ligands, it is possible to prepare a variety of functionalized and flexibly tuned 3D architectures by altering the nature of carboxylate and pillaring ligands. ${ }^{31,38,39}$ We combine (i) in-situ infrared (IR) spectroscopy, (ii) ex-situ Raman spectroscopy, and (iii) powder X-ray diffraction to investigate the reaction of water molecules with the prototypical frameworks $\mathrm{M}(\mathrm{bdc})(\mathrm{ted})_{0.5}$ with paddle-wheel type secondary building units (SBUs). IR and Raman spectroscopy techniques have proved to be useful in studying weak interactions of small molecules in MOFs such as hydrogen and $\mathrm{CO}_{2}$ in MOFs. ${ }^{40-44}$ and in providing information about water bonding, as previously demonstrated for characterizing adsorbed water in MOF materials. ${ }^{45}{ }^{46}$ Raman spectroscopy provides complementary information to IR, and enables the characterization of metal oxide vibrational modes of the MOF that occur in the low frequency region $\left(50-600 \mathrm{~cm}^{-1}\right){ }^{47}$

In this work, IR, Raman and X-ray diffraction measurements are combined with first principles theoretical van der Waals density functional (vdW-DF) calculations. We find that the nature of the central metal ion in $\mathrm{M}(\mathrm{bdc})(\mathrm{ted})_{0.5}$ critically affects the stability and decomposition pathways in humid environments.

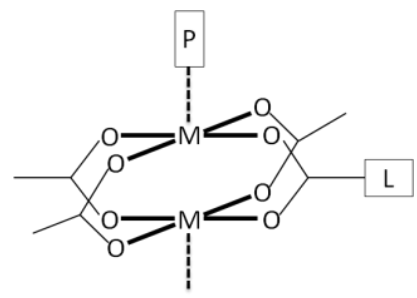

Figure 1. Schematic illustration of coordination geometry of paddle wheel building units: $\mathrm{M}=$ Metal ion, $\mathrm{L}=$ Bicarboxylate linker and $\mathrm{P}=\mathrm{N}$-containing bidentate pillar linker.

\section{Experimental and Theoretical Methods}

Synthesis.
$\mathrm{Cu}(\mathrm{bdc})(\mathrm{ted})_{0.5}$.

A mixture of copper (II) nitrate trihydrate $(0.039 \mathrm{~g})$, $\mathrm{H}_{2} \mathrm{bdc}(0.068 \mathrm{~g})$, ted $(0.048 \mathrm{~g})$ and $15 \mathrm{ml}$ of DMF was transferred into a $20 \mathrm{~mL}$ vessel. The vessel was then sealed and heated to $120{ }^{\circ} \mathrm{C}$ overnight. A blue color crystalline powder was obtained. After filtering and washing with $20 \mathrm{~mL}$ DMF, the product was collected. Then the sample was heated at $120{ }^{\circ} \mathrm{C}$ again under a flow of dry $\mathrm{N}_{2}$ for one day to remove the guest DMF molecules.

$\mathrm{Zn}(\mathrm{bdc})(\mathrm{ted})_{0.5}$.

A mixture of zinc (II) nitrate hexahydrate $(0.245 \mathrm{~g}, 0.82$ mmol), $\mathrm{H}_{2} \mathrm{bdc}(0.136 \mathrm{~g}, 0.97 \mathrm{mmol})$, ted $(0.073 \mathrm{~g}, 0.65 \mathrm{mmol})$ and $15 \mathrm{~mL}$ of DMF were transferred to Teflon-lined autoclave and heated at $120^{\circ} \mathrm{C}$ for 2 days. Cubic colorless crystals of $\mathrm{Zn}(\mathrm{bdc})(\text { ted })_{0.5}$ were isolated by filtering and washed three times with $10 \mathrm{~mL}$ of DMF. Then the sample was heated at $120{ }^{\circ} \mathrm{C}$ again under a flow of dry $\mathrm{N}_{2}$ for one day to remove the guest DMF molecules.

$\mathrm{Ni}(\mathrm{bdc})(\text { ted })_{0.5}$.

A mixture of nickle (II) chloride hexahydrate $(0.107 \mathrm{~g}, 0.45$ $\mathrm{mmol}), \mathrm{H}_{2} \mathrm{bdc}(0.060 \mathrm{~g}, 0.36 \mathrm{mmol})$, ted $(0.033 \mathrm{~g}, 0.29 \mathrm{mmol})$ and $15 \mathrm{ml}$ of DMF were transferred to Teflon-lined autoclave and heated at $120{ }^{\circ} \mathrm{C}$ for 2 days. Green crystalline powder of $\mathrm{Zn}(\mathrm{bdc})(\text { ted })_{0.5}$ was isolated by filtering and washed three times with $10 \mathrm{~mL}$ of DMF. Then the sample was heated at $120{ }^{\circ} \mathrm{C}$ again under a flow of dry $\mathrm{N}_{2}$ for one day to remove the guest DMF molecules.

Co(bdc)(ted) $)_{0.5}$.

A mixture of cobalt (II) nitrate hexahydrate $(0.13 \mathrm{~g}, 0.45$ $\mathrm{mmol}), \mathrm{H}_{2} \mathrm{bdc}(0.060 \mathrm{~g}, 0.36 \mathrm{mmol})$, ted $(0.033 \mathrm{~g}, 0.29 \mathrm{mmol})$ and $15 \mathrm{~mL}$ of DMF were transferred to Teflon-lined autoclave and heated at $120{ }^{\circ} \mathrm{C}$ for 2 days. Purple crystalline powder of $\mathrm{Zn}(\mathrm{bdc})(\text { ted })_{0.5}$ was isolated by filtering and washed three times with $10 \mathrm{~mL}$ of DMF. Then the sample was heated at $120^{\circ} \mathrm{C}$ again under a flow of dry $\mathrm{N}_{2}$ for one day to remove the guest DMF molecules.

Infrared spectroscopy:

A powder of $\mathrm{M}(\mathrm{bdc})(\mathrm{ted})_{0.5}(\sim 2 \mathrm{mg})$ was pressed onto a $\mathrm{KBr}$ support and placed into a high pressure high temperature cell purchased from Specac at the focal point of the sample compartment of infrared spectrometer (Nicolet 6700, Thermo Scientific) equipped with a liquid $\mathrm{N}_{2}$-cooled MCT-B detector. The cell was connected to a vacuum line for evacuation. To avoid interference between the infrared absorption bands of trace amount of unreacted $\mathrm{H}_{2}$ bdc molecules and of $\mathrm{H}_{2} \mathrm{O}, \mathrm{D}_{2} \mathrm{O}$ vapor was used in the water vapor exposure experiments aimed at observing hydrolysis products of BDC ligands. All spectra were recorded in transmission between 400 and $4000 \mathrm{~cm}^{-1}$ (4 $\mathrm{cm}^{-1}$ spectral resolution). A gas phase reference was taken at 
each pressure with a pure $\mathrm{KBr}$ pellet as reference for subtraction.

\section{Raman Spectroscopy.}

The Raman measurements were collected using a Nicolet Almega XR Dispersive Raman spectrometer from Thermofisher. A $532 \mathrm{~nm}$ solid state laser was used for excitation. The output power was reduced to $10 \%(1.23 \mathrm{~mW})$ and the acquisition time varied from 5 to $10 \mathrm{~min}$ to avoid sample decomposition. The spectra were obtained from 50 to $2000 \mathrm{~cm}^{-1}$ with a resolution of $0.9642 \mathrm{~cm}^{-1}$. The spectrometer was equipped with a 50 objective microscope. A larger quantity of $\mathrm{M}(\mathrm{bdc})(\mathrm{ted})_{0.5}$ powder $(\sim 8 \mathrm{mg})$ exposed to similar conditions to the IR experiments was used for ex situ Raman and XRD measurements.

X-ray powder diffraction.

Out of plane X-ray powder diffraction data were recorded in the 2 theta mode from $5^{\circ}$ to $50^{\circ}$ on Rigaku Ultima III diffractometer (Cu Ka radiation, X-ray wavelength of $1.5418 \AA$, operating at $40 \mathrm{keV}$ with a cathode current of $44 \mathrm{Ma}$ ).

vdW-DF calculations.

Calculations were performed using the vdW-DF functional as available in the PWscf code (a Quantum ESPRESSO package). ${ }^{48}$ The vdW-DF ${ }^{49-51}$ functional has been recently shown as a very promising tool for describing van der Walls forces acting in the adsorption of some non-polar molecules in MOF. ${ }^{52}$ Ultrasoft pseudopotentials together with plane-waves, with an optimized cutoff of $35 \mathrm{Ry}$, were used to describe the charge density of the $\mathrm{M}(\mathrm{bdc})(\text { ted) })_{0.5} \mathrm{MOF}$. An accurate sampling of potential energy surface was ensured by imposing tight thresholds on both the total energy, $5^{*} 10^{-12} \mathrm{Ry}$, and forces, $5^{*} 10^{-4} \mathrm{Ry}$ Bohr ${ }^{-1}$. The total energy was sampled on 222 k-point grid according to the Monkost-Pack scheme. ${ }^{53}$ Our analysis is only restricted to the $\mathrm{Ni}$

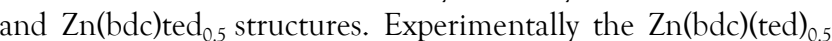
structure is affected by some proton statistical disorder (previously solved by Kong et al. $^{52}$ ) resulting in a tetragonal cell with $a=b=10.93$ and $c=9.61 \AA$. The $\mathrm{Ni}(\mathrm{bdc})(\text { ted })_{0.5}$ was obtained after full relaxation of the $\mathrm{Zn}(\mathrm{bdc})(\mathrm{ted})_{0.5}$ where $\mathrm{Zn}$ atoms were replaced by $\mathrm{Ni}$ atoms. The optimized lattice constants for $\mathrm{Ni}(\mathrm{bdc})(\text { ted })_{0.5}$ are $a=, b=11.15$ and $c=9.53 \AA$. Our initial investigation on the $\mathrm{Ni}(\mathrm{bdc}) \operatorname{ted}_{0.5}$ structure shows that the magnetic moment on the $\mathrm{Ni}$ atoms ( 2 per cell) is 1.76 $\mu_{\mathrm{b}} \mathrm{Ni}^{-1}$ and remains almost totally localized on the $\mathrm{Ni}$ species

\section{Results}

\subsection{IR Spectroscopy}

The assignment of the MOFs vibrational modes is a necessary step toward determining the structural changes occurring upon gas uptake from the vibrational spectra. The structure of $\mathrm{Cu}(\mathrm{bdc})(\text { ted })_{0.5}$ contains two organic linkers 1,4. benzenedicarboxylic acid, triethylenediamine and metal oxide clusters. The IR spectrum of activated $\mathrm{Cu}(\mathrm{bdc})(\mathrm{ted})_{0.5}$ is do minated by the bands associated with the organic parts of the MOF. The infrared spectra of the bdc acid and its related compound have been studied in-depth in the past few years. ${ }^{54.56}$ The fundamental vibrations of ted molecules in the gas,

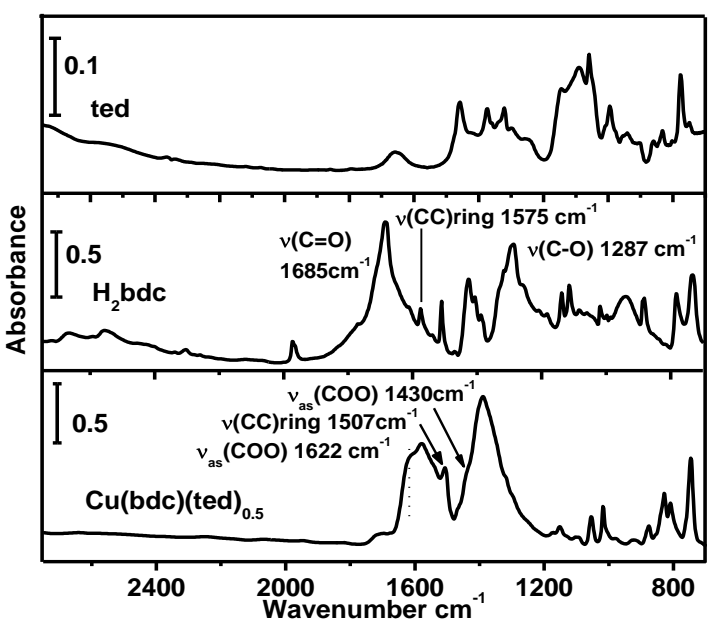

Figure 2. IR adsorption spectra of ted, $\mathrm{H}_{2} \mathrm{bdc}$, and activated $\mathrm{Cu}(\mathrm{bdc})(\text { ted })_{0.5}$ in vacuum referenced to $\mathrm{KBr}$ in vacuum.

solution and solid phases have also previously been assigned. ${ }^{57}$ These studies, together with spectra of pure organic ligands of $\mathrm{H}_{2}$ bdc acids and ted linkers, make it possible to derive a detailed assignment of the MOF vibrational modes. In the paddlewheel structure, the carboxylate ion $\mathrm{COO}^{-}$is coordinated to two $\mathrm{Cu}$ atoms as a bridging bidentate ligand in a syn-syn configuration as shown in Fig. 1. The $-\mathrm{COO}^{\circ}$ group is characterized by in phase or out of phase vibrations of the two equivalent $\mathrm{C}-\mathrm{O}$ bonds, leading to the symmetric and antisymmetric stretch modes. Previous work has suggested that the splitting $\Delta$ between these two $v(\mathrm{COO})$ frequencies is related to the nature of the carboxylate coordination. ${ }^{58,59}$ For example, carboxylate with bridging bidentate configuration gives values in the range of $160-200 \mathrm{~cm}^{-1}$ similar to vibrations of ionic species. ${ }^{58}$ The intensity of the asymmetric mode is usually larger than that of symmetric stretching mode. ${ }^{60}$ Large splittings $(>200$ $\mathrm{cm}^{-1}$ ) are usually associated with monodentate carboxylate due to a change from equivalent to inequivalent carbon-oxygen bonds. ${ }^{58}$ In bidentate bridged carboxylate-Cu(II) complexes, the $v_{\text {as }}(\mathrm{COO})$ species is usually characterized by a wavenumber in the $1600-1630 \mathrm{~cm}^{-1}$ region. ${ }^{61,62}$ On the basis of all this previous work, we assign the band at $1622 \mathrm{~cm}^{-1}$, overlapped with an intense band at $1575 \mathrm{~cm}^{-1}$, to out of phase (IR active) motion of asymmetric stretch $v_{\mathrm{as}}(\mathrm{COO})$. The intense band at $1575 \mathrm{~cm}^{-1}$, as well as those at $1507 \mathrm{~cm}^{-1}, 1152 \mathrm{~cm}^{-1}$ and $1017 \mathrm{~cm}^{-1}$ are all associated with the phenyl modes, based on the comparison with pure bdc ligands and reference assignments. ${ }^{54-56}$ Considering the relationship between the separation $\Delta$ of the two $v(\mathrm{COO})$ frequencies and the nature of the carboxylate coordination, we infer that, since the $v_{\text {antisym }}(\mathrm{COO})$ is at 1622 $\mathrm{cm}^{-1}$, the symmetric stretch mode of $v_{\text {sym }}(\mathrm{COO})$ should be 
higher than $1420 \mathrm{~cm}^{-1}$ and the intensity of $v_{\text {sym }}(\mathrm{COO})$ weaker than the band at $1622 \mathrm{~cm}^{-1}$. Based on this consideration, we assign the shoulder at 1430 $\mathrm{cm}^{-1}$ rather than the strong peak at $1391 \mathrm{~cm}^{-1}$ to $v_{\text {sym }}(\mathrm{COO})$.

Table 1. Selected IR, Raman Frequencies $\left(\mathrm{cm}^{-1}\right)$ and their assignment for $\mathrm{Cu}(\mathrm{bdc})(\mathrm{ted})_{0.5}{ }^{\mathrm{a}}$

\begin{tabular}{|c|c|c|}
\hline IR & Raman & Assignment \\
\hline 1622, & 1535 & $\mathbf{v}_{\text {as }}(\mathrm{COO})$ \\
\hline 1575,1507 & & $19 \mathrm{a}, 19 \mathrm{~b}, 18 \mathrm{~b}$ and $18 \mathrm{a}$ \\
\hline & & $8 \mathrm{a} \mathrm{CC}$ stretching \\
\hline 1430 & 1617 & $\mathbf{v}_{\mathrm{s}}(\mathrm{COO})$ \\
\hline 1054 & 1442,1430 & $\mathbf{v}_{\mathrm{as}}(\mathrm{NC})$ \\
\hline 874 & & $\gamma(\mathrm{CH})_{\text {oop }}$ \\
\hline 828 & & $\boldsymbol{\rho}(\mathrm{CH}))$ \\
\hline 810 & & $\boldsymbol{\delta}(\mathrm{COO})_{\text {op }}$ \\
\hline & & $\boldsymbol{\delta}(\mathrm{COO})_{\text {ip }}$ \\
\hline 744 & 727 & 12 ring deformation \\
\hline & & $\mathbf{v}(\mathrm{Cu}-\mathrm{O})$ \\
\hline
\end{tabular}

${ }^{a}$ The numbers 19a, 19b, 18b, 18a, 8a and 12 represents Wilson notation to describe the phenyl vibrational modes: $19 \mathrm{a}$ and $19 \mathrm{~b}$ contain the mixture of the $\mathrm{v}(\mathrm{C}=\mathrm{C})$ and $\mathrm{CH}$ bending motions; $18 \mathrm{a}$ and $18 \mathrm{~b}$ are classified as the mode having $\mathrm{CH}$ bending character. $8 \mathrm{a}$ mode is assigned to $\mathrm{CC}$ stretching under $\mathrm{C}_{\mathrm{i}}$ symmetry. 12 is attributed to the benzene trigonal ring deformation.

This intense band at $1391 \mathrm{~cm}^{-1}$ also appears in spectrum of the Cu-btc sample (btc=1,3,5-benzenetricarboxylate) and Ni-based MOFs containing paddle-wheel type inorganic building units, and is therefore attributed to the benzene ring mode. ${ }^{37,62,63}$ Since it is not directly connected with the central metal ions, it is the least affected by substitution of central metal ions. The presence of this bands at the same frequency $\left(1391 \mathrm{~cm}^{-1}\right)$ in the other three $\mathrm{M}(\mathrm{bdc})(\mathrm{ted})_{0.5}$ series $[\mathrm{M}=\mathrm{Zn}, \mathrm{Ni}, \mathrm{Co}]$ indicates that it is independent of metal centers like the band at $1507 \mathrm{~cm}^{-1}$. The band at $810 \mathrm{~cm}^{-1}$ is assigned to the $\delta(\mathrm{COO})$ oop (IR active), while the Raman active band $\delta(\mathrm{COO})$ ip is at $727 \mathrm{~cm}^{-1}$. Other assignments are listed in Table 1. By applying the same reasoning, we assign the other $\mathrm{M}(\mathrm{bdc})(\mathrm{ted})_{0.5}$ series, as shown in Fig. S3 (Supporting Information).

To select the experimental conditions, we note that Liang's $\mathrm{H}_{2} \mathrm{O}$ vapor adsorption isotherm and X-ray powder pattern studies showed that the structures of two isostructural MOFs $\mathrm{M}(\mathrm{bdc})(\text { ted })_{0.5}(\mathrm{M}=\mathrm{Zn}, \mathrm{Ni})$ remain stable under $30 \%$ relative humidity at $25{ }^{\circ} \mathrm{C}$, yet collapse under $60 \%$ relative humidity. ${ }^{64}$
For our work we therefore chose two pressures: 6 Torr, the common relative humidity $30 \%$ in atmosphere and 9.5 Torr $\mathrm{D}_{2} \mathrm{O}$ vapor, relative humidity $48 \%$ at room temperature of $24^{\circ} \mathrm{C}$.

After introduction of 6 Torr $\mathrm{D}_{2} \mathrm{O}$ at room temperature, a broad band associated with the stretching modes of adsorbed $\mathrm{D}_{2} \mathrm{O}$ appears in the region from 2700 to $1800 \mathrm{~cm}^{-1}$ in all four
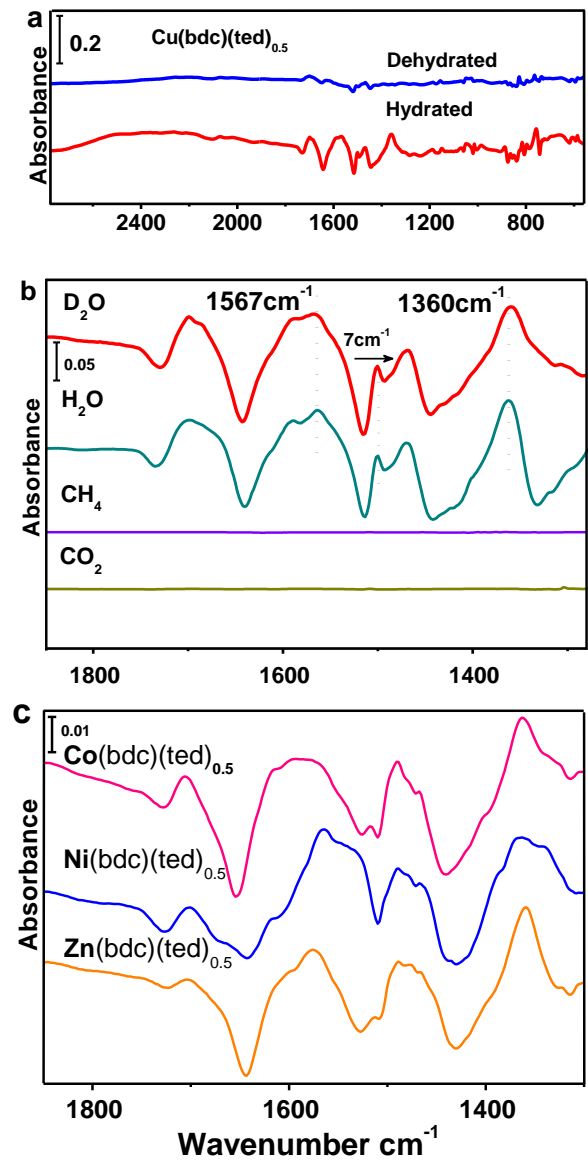

Figure 3. (a): IR absorption spectra of $\mathrm{Cu}(\mathrm{bdc})(\mathrm{ted})_{0.5}$ exposure to 6 Torr $\mathrm{D}_{2} \mathrm{O}$ vapor (red spectrum), dehydrated $\mathrm{Cu}(\mathrm{bdc})(\text { ted) })_{0.5}$ after evacuation at $413 \mathrm{~K}$ (blue spectrum). Both spectra are referenced to activated $\mathrm{Cu}(\mathrm{bdc})(\text { ted })_{0.5}$. (b): The middle frequency range of $\mathrm{Cu}(\mathrm{bdc})(\text { ted })_{0.5}$ exposure to 6 Torr $\mathrm{D}_{2} \mathrm{O}$ vapor, $\mathrm{H}_{2} \mathrm{O}$ vapor, $\mathrm{CH}_{4}$, and $\mathrm{CO}_{2}$. (c): IR absorption spectra of $\mathrm{Zn}(\mathrm{bdc})(\mathrm{ted})_{0.5}$, $\mathrm{Ni}(\mathrm{bdc})(\text { ted })_{0.5}$, and $\mathrm{Co}(\mathrm{bdc})(\text { ted })_{0.5}$ exposure to 6 Torr $\mathrm{D}_{2} \mathrm{O}$.

compounds (See Fig. 3a and Fig. S15). Furthermore, the IR absorption spectrum of $\mathrm{Cu}(\mathrm{bdc})(\text { ted })_{0.5}$ is strongly affected after $\mathrm{D}_{2} \mathrm{O}$ exposure in the middle frequency range from 1800 to $1300 \mathrm{~cm}^{-1}$, away from the $\mathrm{D}_{2} \mathrm{O}$ bending mode region (around $\left.1200 \mathrm{~cm}^{-1}\right)$. For this MOF $\left[\mathrm{Cu}(\mathrm{bdc})(\text { ted })_{0.5}\right]$, a red shift of the $\mathrm{v}(\mathrm{C}=\mathrm{O})$ mode from 1730 to $1700 \mathrm{~cm}^{-1}$ is due to deuterium bonding of the $\mathrm{C}=\mathrm{O}$ bond with the incoming $\mathrm{D}_{2} \mathrm{O}$ molecule. The red shift of $7 \mathrm{~cm}^{-1}$ of the mode at $1507 \mathrm{~cm}^{-1}$ (Fig. 3b) is related to perturbation of the benzene ring stretching band $19 \mathrm{~b}$ of $\mathrm{Cu}(\mathrm{bdc})(\text { ted })_{0.5}$. The two new features at $1360 \mathrm{~cm}^{-1}$ and 1567 $\mathrm{cm}^{-1}$ arising upon introduction of $\mathrm{D}_{2} \mathrm{O}$ molecules are attributed to $v_{\mathrm{as}}(\mathrm{COO})$ and $v_{\mathrm{s}}(\mathrm{COO})$, initially at $\sim 1600-1640 \mathrm{~cm}^{-1}$ and 
$\sim 1410-1430 \mathrm{~cm}^{-1}$, as discussed in next section. To distinguish and identify the role of water vapor in inducing these spectral changes, nonpolar gases $\left(\mathrm{CH}_{4}, \mathrm{CO}_{2}\right)$ exposures were also performed under the same conditions. As shown in Fig. 3b, little change results from non-polar $\mathrm{CO}_{2}$ and $\mathrm{CH}_{4}$ molecules. In contrast, the same large perturbations for $\mathrm{Cu}(\mathrm{bdc})(\text { ted })_{0.5}$ are noted upon $\mathrm{H}_{2} \mathrm{O}$ exposure upon $\mathrm{D}_{2} \mathrm{O}$ exposure. As shown Fig. $3 \mathrm{c}$, the same perturbation bands are identified in the frequency region of 1800 to $1350 \mathrm{~cm}^{-1}$ in the

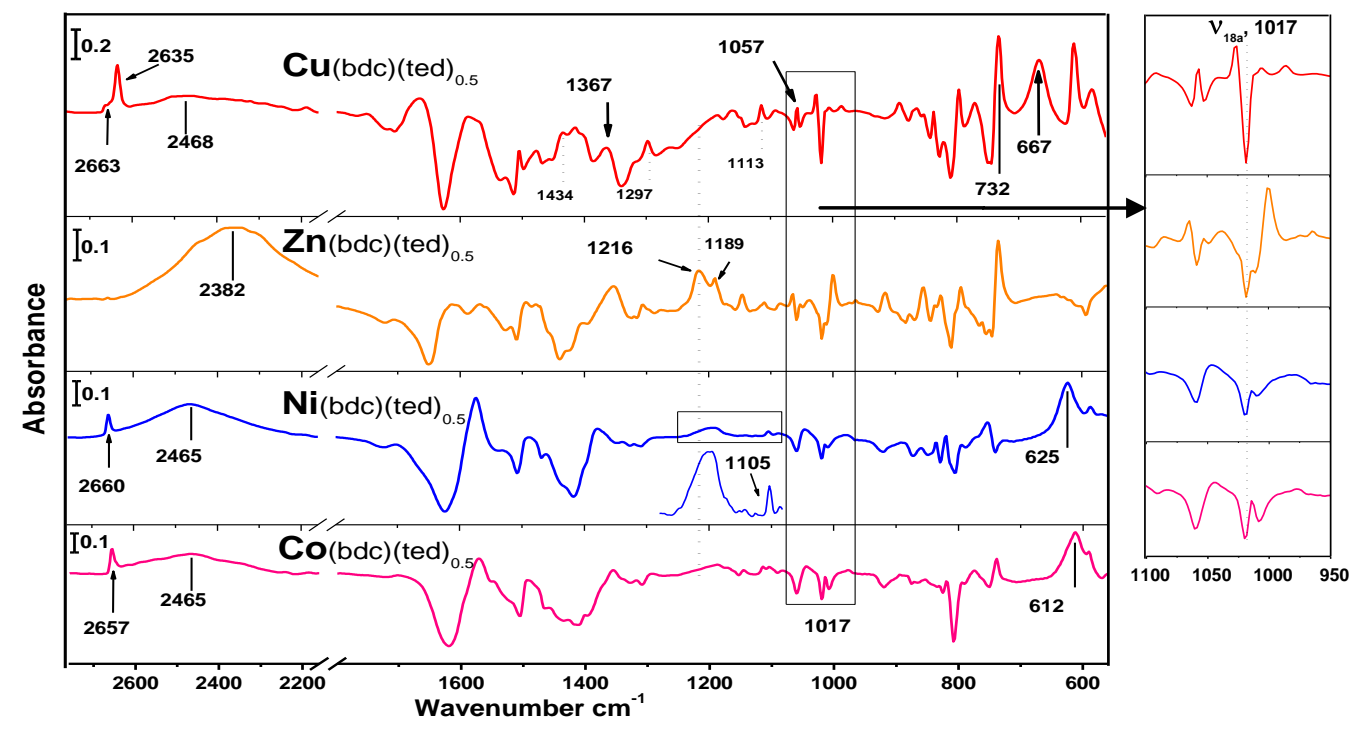

Figure 4. IR adsorption spectra of hydrated $\mathrm{M}(\mathrm{bdc})(\text { ted })_{0.5}$, referenced to activated $\mathrm{MOF}$ in vacuum after introduction of $9.5 \mathrm{Torr} \mathrm{D}_{2} \mathrm{O}$ vapor and evacuation of gas phase $\mathrm{D}_{2} \mathrm{O}$ vapor. Color scheme: red, $\mathrm{Cu}(\mathrm{bdc})(\text { ted })_{0.5} ;$ black, $\mathrm{Zn}(\mathrm{bdc})(\text { ted })_{0.5}$, blue, $\mathrm{Ni}(\mathrm{bdc})(\text { ted })_{0.5} ;$ pink, Co(bdc)(ted) $)_{0.5}$.

other three $\mathrm{M}(\mathrm{bdc})(\mathrm{ted})_{0.5}[\mathrm{M}=\mathrm{Zn}, \mathrm{Ni}, \mathrm{Co}]$ compounds. Further experiments of the pressure dependence of $\mathrm{D}_{2} \mathrm{O}$ adsorption into $\mathrm{M}(\mathrm{bdc})(\text { ted) })_{0.5}$ (see Fig. S15) also confirm that these intensity variations are associated with incorporation of $\mathrm{D}_{2} \mathrm{O}$ molecules into the frameworks. This conclusion is confirmed by evacuating the sample at $413 \mathrm{~K}$ overnight after $\mathrm{D}_{2} \mathrm{O}$ gas loading at 6 Torr, and noting that both $\mathrm{D}_{2} \mathrm{O}$-related absorption and all spectral perturbations are nearly removed.

Indeed, after exposing the activated sample to 9.5 Torr $\mathrm{D}_{2} \mathrm{O}$, the spectra of all four compounds exhibit distinctive features in the frequency range of $2700-2100 \mathrm{~cm}^{-1}$ (Fig. 4). Sharp components can be seen in $\mathrm{Cu}(\mathrm{bdc})(\text { ted })_{0.5}, \mathrm{Ni}(\mathrm{bdc})(\text { ted })_{0.5}$, and Co(bdc)(ted) 0.5 at the frequencies of 2635, 2660, and $2657 \mathrm{~cm}^{-1}$. In the case of $\mathrm{Cu}(\mathrm{bdc})(\mathrm{ted})_{0.5}$, a small shoulder on a sharp band is observable at $2663 \mathrm{~cm}^{-1}$ and attributed to O-D groups as described below.

The lineshape and position of the broad $v(\mathrm{O}-\mathrm{D})$ absorption bands contain useful information to understand the interaction of adsorbed $\mathrm{D}_{2} \mathrm{O}$ with the $\mathrm{MOF}$ framework. In $\mathrm{Cu}(\mathrm{bdc})(\text { ted })_{0.5}$, $\mathrm{Ni}(\mathrm{bdc})(\text { ted })_{0.5}$, and $\mathrm{Co}(\mathrm{bdc})(\text { ted })_{0.5}$, the band is centered between 2460 to $2480 \mathrm{~cm}^{-1}$. However, in the case of $\mathrm{Zn}(\mathrm{bdc})(\mathrm{ted})_{0.5}$, it is centered around $2380 \mathrm{~cm}^{-1}$, a distinctively lower frequency. In the middle frequency range of 1800 to 950 $\mathrm{cm}^{-1}$, the spectrum of $\mathrm{Cu}(\mathrm{bdc})(\mathrm{ted})_{0.5}$ displays additional adsorption bands, compared to the other three MOFs. These bands are labeled by wavenumbers in Fig. 4. Similar to the stretching mode of broad $v(\mathrm{O}-\mathrm{D})$ bands, the bending mode of $\mathrm{D}_{2} \mathrm{O}$ in $\mathrm{Zn}(\mathrm{bdc})(\mathrm{ted})_{0.5}$ is also distinctively different from that in the other three compounds: a peak develops at higher frequency $\left(1216 \mathrm{~cm}^{-1}\right)$. The $v_{18 \mathrm{a}}$ mode of the bdc ligand situated at $1017 \mathrm{~cm}^{-1}$ in four compounds responds to hydration by different ways: it blue shifts to $1027 \mathrm{~cm}^{-1}$ in the case of $\mathrm{Cu}(\mathrm{bdc})(\text { ted })_{0.5}$ but red shifts to $1013 \mathrm{~cm}^{-1}$ in $\mathrm{Ni}(\mathrm{bdc})(\text { ted })_{0.5}$ and $\mathrm{Co}(\mathrm{bdc})(\text { ted) })_{0.5}$; in the case of $\mathrm{Zn}(\mathrm{bdc})(\text { ted })_{0.5}$, it undergoes a larger red shift to $1001 \mathrm{~cm}^{-1}$. In fact, this band is sensitive to the MOF structural changes and has been used before to monitor the transformation of flexible frameworks MIL-53 $\left[\mathrm{CrIII}(\mathrm{OH})\left(\mathrm{OOC}-\mathrm{C}_{6} \mathrm{H}_{4}-\mathrm{COO}\right)\right]$ during $\mathrm{CO}_{2}$ adsorption and dehydration processes. ${ }^{46,65}$ In the low frequency range below $800 \mathrm{~cm}^{-1}$, a broad band is observed at $667 \mathrm{~cm}^{-1}$ in the $\mathrm{Cu}(\mathrm{bdc})(\text { ted })_{0.5}$ but absent in other three compounds. In $\mathrm{Ni}(\mathrm{bdc})(\text { ted })_{0.5}$ and $\mathrm{Co}(\mathrm{bdc})(\text { ted })_{0.5}$, new bands appear at 626 $\mathrm{cm}^{-1}$ and $612 \mathrm{~cm}^{-1}$ only after exposure to 9.5 Torr $\mathrm{D}_{2} \mathrm{O}$ vapor (i.e. they are absent in the low vapor exposure regime).

In the desorption process, the removal of trapped $\mathrm{D}_{2} \mathrm{O}$ requires a higher annealing temperature for $\mathrm{Zn}(\mathrm{bdc})(\mathrm{ted})_{0.5}$ than for the other MOFs of the series $(\mathrm{Cu}, \mathrm{Ni}, \mathrm{Co})$. Fig. 5 shows a slow release of bound $\mathrm{D}_{2} \mathrm{O}$ molecules in $\mathrm{Zn}(\mathrm{bdc})(\text { ted })_{0.5}$ up to $200{ }^{\circ} \mathrm{C}$. For the other MOF compounds, the $\mathrm{D}_{2} \mathrm{O}$ molecules are completely removed at $100{ }^{\circ} \mathrm{C}$ under vacuum. 


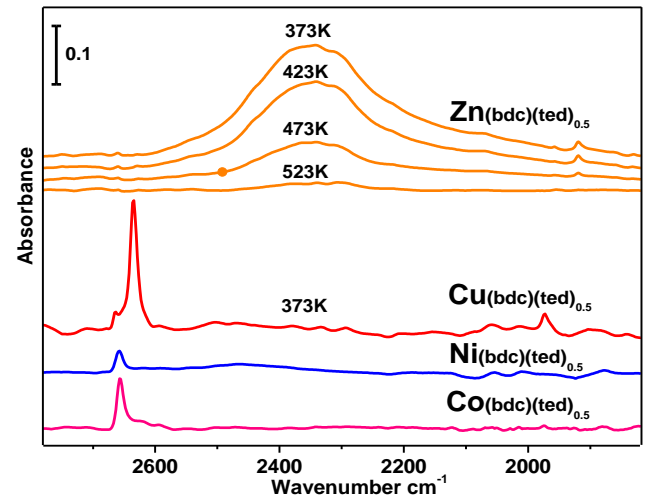

Figure 5. IR spectra of hydrated $M($ bdc $)(\text { ted })_{0.5}[\mathrm{M}=\mathrm{Zn}, \mathrm{Cu}, \mathrm{Ni}, \mathrm{Co}]$ after evacuation at elevated temperature, referenced to activated sample recorded at RT. Color scheme: Orange, $\mathrm{Zn}(\mathrm{bdc})($ ted) 0.5 after outgassing for $10 \mathrm{~h}$ at $373 \mathrm{~K}, 423 \mathrm{~K}, 473 \mathrm{~K}$, and $2 \mathrm{~h}$ at $523 \mathrm{~K}$; Red, blue, and pink corresponding to $\mathrm{Cu}(\mathrm{bdc})(\mathrm{ted})_{0.5}$, $\mathrm{Ni}(\mathrm{bdc})(\mathrm{ted})_{0.5}$ and $\mathrm{Co}(\mathrm{bdc})(\mathrm{ted})_{0.5}$ after outgassing for $10 \mathrm{~h}$ at 373 K.

\subsection{Raman Spectroscopy}

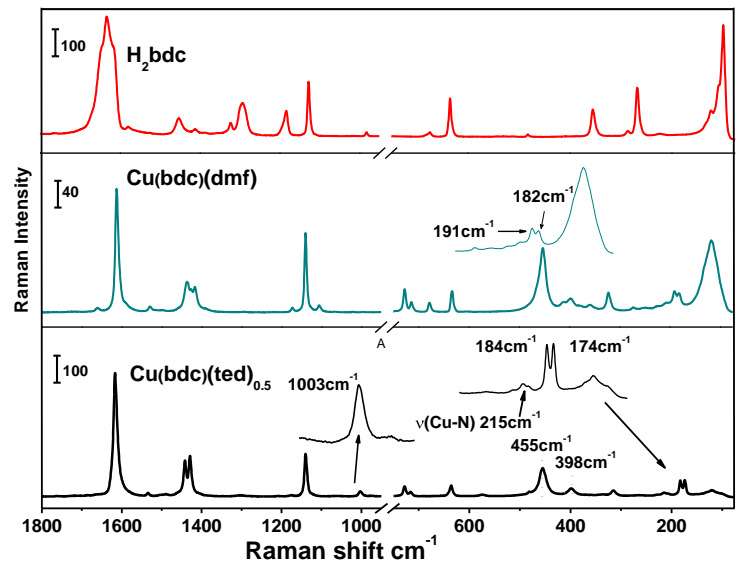

Figure 6. Raman spectra from top to bottom: $\mathrm{H}_{2} \mathrm{bdc}$ acid, $\mathrm{Cu}(\mathrm{bdc})(\mathrm{dmf})$ and $\mathrm{Cu}(\mathrm{bdc})(\text { ted })_{0.5}$.

The vibrational assignments of $\mathrm{M}(\mathrm{bdc})(\mathrm{ted})_{0.5}$ are best performed by comparing the Raman spectra of $\mathrm{M}(\mathrm{bdc})(\mathrm{ted})_{0.5}$ to those of free $\mathrm{H}_{2}$ bdc molecules, ted ligands and the counterpoint $\mathrm{M}(\mathrm{bdc})(\mathrm{dmf})$ in Fig 6. For example, $\mathrm{Cu}(\mathrm{bdc})(\mathrm{dmf})$ was synthesized in the same conditions as $\mathrm{Cu}(\mathrm{bdc})(\mathrm{ted})_{0.5}$ in the absence of ted ligands. The structure of $\mathrm{Cu}(\mathrm{bdc})(\mathrm{dmf})$, resembling the structure of $\mathrm{Cu}(\mathrm{bdc})(\mathrm{ted})_{0.5}$, is formed of a three-dimensional network structure bridging the two-dimensional layers of porous copper(II) dicarboxylate with DMF solvent instead of pillar ligand of ted shown in middle part of Fig. $6 .{ }^{66}$ In the high frequency range $\left(1800\right.$ to $\left.900 \mathrm{~cm}^{-1}\right)$, most of the Raman bands are due to vibrational modes of bdc linkers. The band at $1617 \mathrm{~cm}^{-1}$ is assigned to the phenyl mode $v_{8 \mathrm{a}}[\mathrm{C}=\mathrm{C}$ stretching mode of bdc] that only appears in the Raman spectra because it has $\mathrm{g}$ parity under $\mathrm{C}_{i}$ symmetry. ${ }^{54}$ While the feature at $1535 \mathrm{~cm}^{-1}$ is due to in-plane $v_{\text {asym }}(\mathrm{COO})$, the bands at $1442 \mathrm{~cm}^{-1}$ and 1430 $\mathrm{cm}^{-1}$ can be assigned to $v_{\mathrm{sym}}(\mathrm{COO})$. The vibrational frequencies of the symmetric and antisymmetric $v(\mathrm{COO})$ modes are different from the corresponding modes detected in IR measurements because they are in-phase (Raman-active) motions of asymmetric and symmetric $\mathrm{CO}_{2}$ stretching, instead of out-ofphase (IR active).

In the low frequency region (750 to $\left.50 \mathrm{~cm}^{-1}\right), \mathrm{Cu}(\mathrm{bdc})(\text { ted })_{0.5}$ exhibits a more complex Raman spectrum than that of acid molecules because of the presence of vibrational modes of metal $(\mathrm{Cu})$ oxide clusters. The vibrational features of metal oxide clusters can be assigned by comparing to $\mathrm{Cu}(\mathrm{bdc})(\mathrm{dmf})$, copper acetate monohydrate $\mathrm{Cu}(\mathrm{OAc})_{2}\left(\mathrm{H}_{2} \mathrm{O}\right)_{2}{ }^{67}$, exhibiting the same $\left[\mathrm{Cu}_{2} \mathrm{C}_{4} \mathrm{O}_{8}\right]$ cage as $\mathrm{Cu}(\mathrm{bdc})(\mathrm{ted})_{0.5}$, copper paddle-wheel-based MOFs Cu-btc [btc $=1,3,5$-benzenetricarboxylate], ${ }^{47}$ and the $\mathrm{M}(\mathrm{bdc})(\text { ted })_{0.5}[\mathrm{M}=\mathrm{Zn}, \mathrm{Ni}, \mathrm{Co}]$ series in Fig. S4. Two bands at $455 \mathrm{~cm}^{-1}$ and $398 \mathrm{~cm}^{-1}$ are definitely attributed to $\mathrm{Cu}-\mathrm{O}$ species and the $316 \mathrm{~cm}^{-1}$ mode can be ascribed to $\mathrm{k}(\mathrm{Cu}-\mathrm{O})$, which is also observed in $\mathrm{Cu}(\mathrm{bdc})(\mathrm{dmf})$ and $\mathrm{Cu}-$ btc compounds. A doublet appears in $\mathrm{Cu}(\mathrm{bdc})(\mathrm{ted})_{0.5}$ at 184 and $174 \mathrm{~cm}^{-1}$, in $\mathrm{Cu}(\mathrm{bdc})(\mathrm{dmf})$ at 191 and $182 \mathrm{~cm}^{-1}$ as well as in Cu-btc at 193 and $177 \mathrm{~cm}^{-1}$ but is absent in pure $\mathrm{H}_{2}$ bdc ligands. Prestipino ascribed these bands to a mode involving $\mathrm{Cu}-\mathrm{Cu}$ stretching of the two $\mathrm{Cu}$ (II) ions of $\mathrm{Cu}_{2}[\mathrm{COO}]_{4}$ framework cage. ${ }^{47}$ For the other three $\mathrm{M}(\mathrm{bdc})(\text { ted })_{0.5}[\mathrm{M}=\mathrm{Zn}, \mathrm{Ni}, \mathrm{Co}]$ compound and $\mathrm{Zn}(\mathrm{bdc})(\mathrm{dmf})$, the doublet mode can be also readily identified around 190-160 $\mathrm{cm}^{-1}$ in Fig. 7 and Fig. S5. These doublets can be regarded as a unique feature of di-nuclear paddle wheel building units. The band at $215 \mathrm{~cm}^{-1}$ can be tentatively assigned to ${ }^{(\mathrm{Cu}-\mathrm{N})}$ bond. ${ }^{67}$

The full Raman spectra for another three compounds $\mathrm{M}(\mathrm{bdc})(\text { ted })_{0.5}[\mathrm{M}=\mathrm{Zn}, \mathrm{Ni}, \mathrm{Co}]$ are presented in the Supporting Information (See Fig. S4). Here what we are interested in are the two regions of 950 to $1200 \mathrm{~cm}^{-1}$ and 100 to $500 \mathrm{~cm}^{-1}$. In four compounds, we can observe a band around 1000 to 1050 $\mathrm{cm}^{-1}$ in Fig. 7 for all activated MOFs. This feature is found neither in $\mathrm{Cu}(\mathrm{bdc})(\mathrm{dmf}), \mathrm{Zn}(\mathrm{bdc})(\mathrm{dmf})$ structures nor in pure bdc ligands (See Fig. S5). It must therefore be associated with the ted ligands. Previous studies have assigned such a band to $v_{4}$ $\left(v \mathrm{CC} / \omega \mathrm{CH}_{2}\right)$ that involves a substantial amount of C-C stretching vibration. ${ }^{68-70}$ In triethylenediamine molecules, the two nitrogen lone pairs are connected by $-\mathrm{CH}_{2}-\mathrm{CH}_{2}-$ chains and interact primarily via through bond coupling. ${ }^{71,72}$ The mixing of the lone pair molecule orbitals with C-C molecule orbitals makes the $v_{4}\left(v \mathrm{CC} / \omega \mathrm{CH}_{2}\right)$ mode frequency extremely sensitive to the changes in the environment of the lone pairs. For the unprotonated species of ted, $v_{4}$ is found at $983 \mathrm{~cm}^{-1}{ }^{68}$ Upon coordination to metal ions $\mathrm{Cu}^{2+}, \mathrm{Co}^{2+}, \mathrm{Ni}^{2+}, \mathrm{Zn}^{2+}$, this band shifts to $1003 \mathrm{~cm}^{-1}, 1009 \mathrm{~cm}^{-1}, 1012 \mathrm{~cm}^{-1}$, and even $1018 \mathrm{~cm}^{-1}$. The coordination of the lone pair to metal ions causes a redistribution of the electron density, releasing the through-bond coupling and resulting in a blue shift of $v_{4}$ in four compounds.

After exposing the activated sample to 9.5 Torr $\mathrm{D}_{2} \mathrm{O}$ vapor, the Raman spectra of hydrated $\mathrm{M}(\mathrm{bdc})(\mathrm{ted})_{0.5}[\mathrm{M}=\mathrm{Zn}, \mathrm{Ni}, \mathrm{Co}]$ show marked changes compared to that of pristine sample (Fig. 7 and Fig. S6). For $\mathrm{Cu}(\mathrm{bdc})(\mathrm{ted})_{0.5}$, the modes in the low frequency region are significantly affected by the hydration process: the doublet mode around 174 to $184 \mathrm{~cm}^{-1}$ that involves the $\mathrm{Cu}-\mathrm{Cu}$ vibration vanishes, and is replaced by a single broad 
peak at $187 \mathrm{~cm}^{-1}$. The hydration process leads to the formation of a mode at $\sim 268 \mathrm{~cm}^{-1}$, which corresponds to the adsorption band of $\mathrm{H}_{2}$ bdc (See Fig. 6). In the high frequency region (950$1100 \mathrm{~cm}^{-1}$ range), the C-C stretching mode $v_{4}$ is left unchanged at $1003 \mathrm{~cm}^{-1}$. For $\mathrm{Zn}(\mathrm{bdc})(\text { ted })_{0.5}$, the doublet mode involving $\mathrm{Zn}-\mathrm{Zn}$ species remains unaffected; the $v_{4}$ mode at $1018 \mathrm{~cm}^{-1}$ disappears while a new band appears at $983 \mathrm{~cm}^{-1}$. For $\mathrm{Ni}(\text { bdc)(ted) })_{0.5}$, the Raman spectra do not significantly change upon hydration. For Co(bdc)(ted) $)_{0.5}$, both the $v_{4}$ and the doublet modes disappear after hydration.

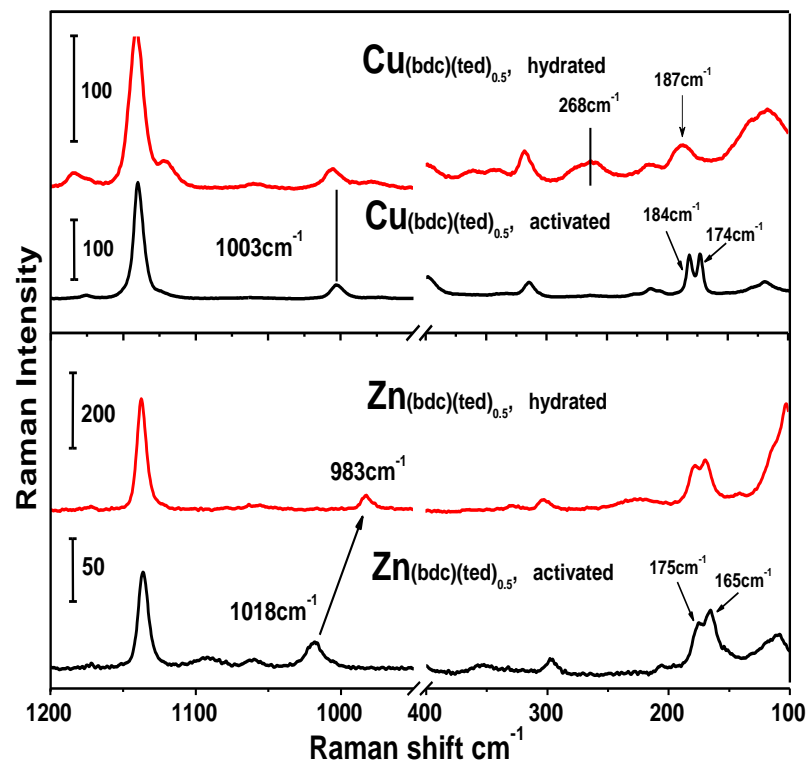

\subsection{X-ray diffraction pattern}

The crystal structure for guest-free $\mathrm{M}(\mathrm{bdc})(\mathrm{ted})_{0.5}$ after activation includes 2D square networks, in which the paddle wheel SBUs $\left[\mathrm{M}_{2}(\mathrm{COO})_{4}\right]$ is linked by bdc ligands within the layer of the square networks (xy plane). The $z$ axial sites of the metal ions are bonded by ted molecules to generate the 3D frameworks. For $\mathrm{Cu}(\mathrm{bdc})(\mathrm{ted})_{0.5}$, all the phases except [001] shift to a higher $2 \theta$ value after hydration (See Fig. 8). For $\mathrm{Zn}(\mathrm{bdc})(\mathrm{ted})_{0.5}$, the framework transforms into another phase

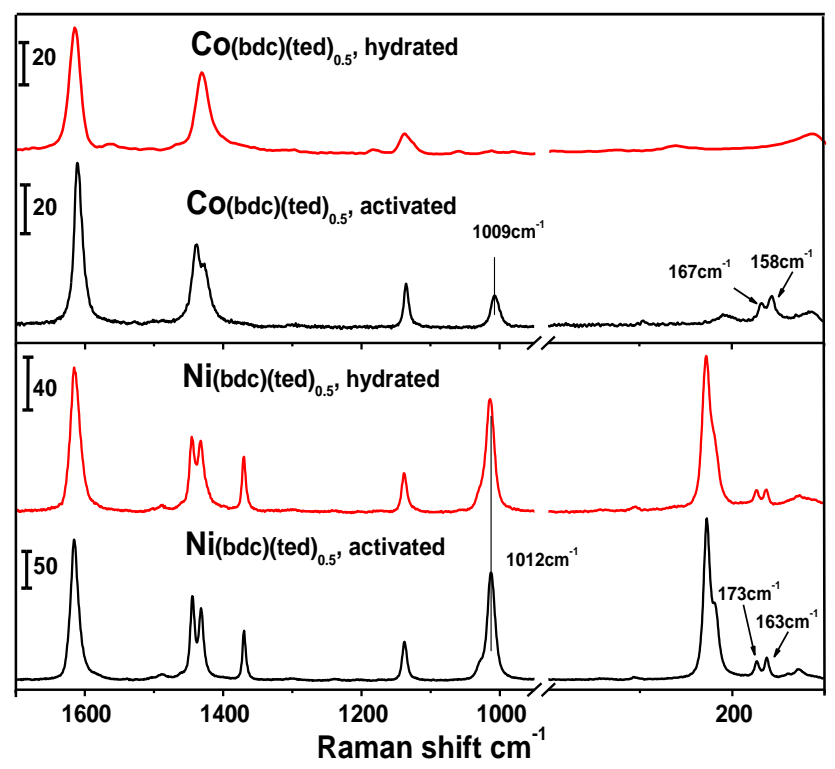

Figure 7. Raman spectra of activated (pristine) MOF samples and hydrated MOF materials after exposing to 9.5 Torr $\mathrm{D}_{2} \mathrm{O}$ vapor.
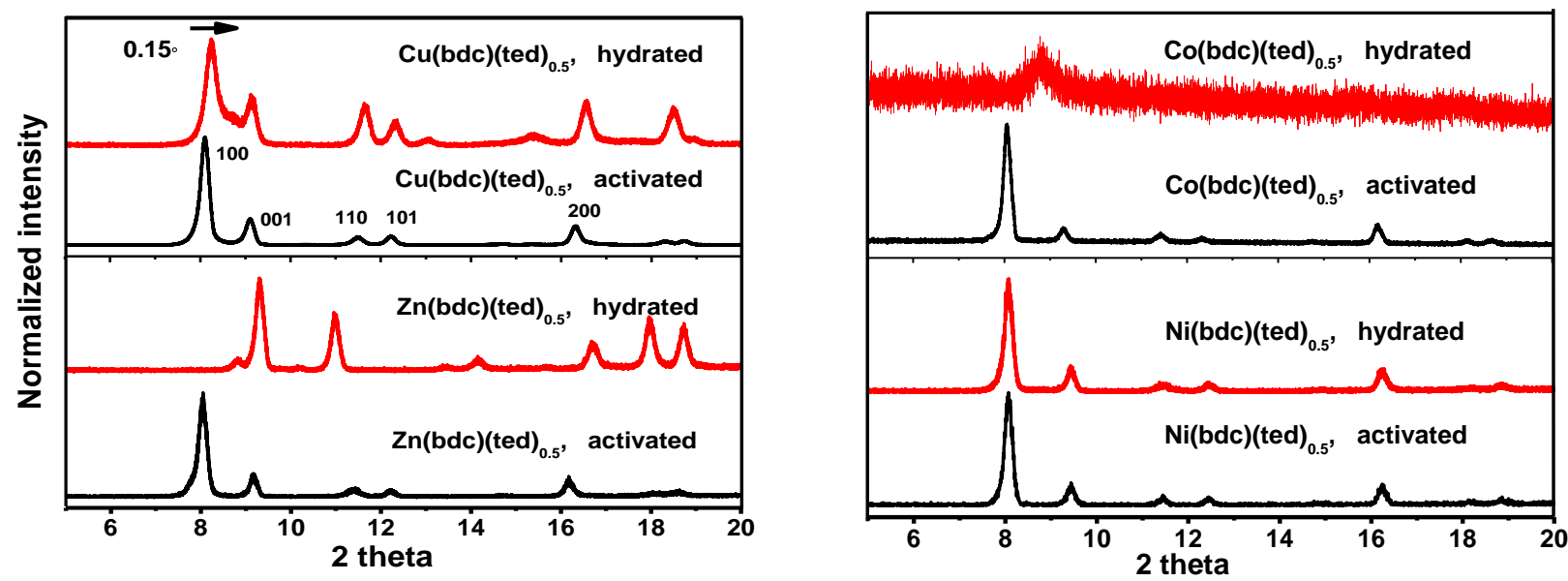

Figure 8. Powder X-ray pattern of hydrated MOF materials exposing to 9.5 Torr $\mathrm{D}_{2} \mathrm{O}$ vapor and activated (pristine) MOF samples.

after exposure to 9.5 Torr $\mathrm{D}_{2} \mathrm{O}$ vapor for $1 \mathrm{~h}$, in a manner similar to MOF-2 as evidenced by several characteristic peaks in Fig. S7. For $\mathrm{Ni}(\mathrm{bdc})(\mathrm{ted})_{0.5}$, the powder X-ray pattern is not affected at all by hydration. In contrast, for $\mathrm{Co}(\mathrm{bdc})(\mathrm{ted})_{0.5}$, the crystal structure is completely destroyed after exposure to 9.5 Torr $\mathrm{D}_{2} \mathrm{O}$ vapor.

\section{Interpretation}

\section{$4.1 \mathrm{Cu}(\mathrm{bdc})(\mathrm{ted})_{0.5}$}

For $\mathrm{M}(\mathrm{bdc})(\mathrm{ted})_{0.5}$, the bdc and ted linkers are hydrophobic organic molecules surrounding a paddle wheel metal-oxide group. Hence, the adsorption sites for polar $\mathrm{D}_{2} \mathrm{O}$ molecules are expected to be near the metal carboxylate. ${ }^{73}$ This can explain 
that the $v_{\text {asym }}(\mathrm{COO})$ and $v_{\text {sym }}(\mathrm{COO})$ bands shift to lower wavenumbers when $\mathrm{D}_{2} \mathrm{O}$ is adsorbed into the frameworks. Powder X-ray diffraction measurements (See Fig. S10) confirm that $\mathrm{Cu}(\mathrm{bdc})(\text { ted) })_{0.5}$ can be stable under low humidity (e.g. 6 Torr $\mathrm{D}_{2} \mathrm{O}$ ) without any major changes in the framework structure. The Raman spectra shown in Fig. S11 remain unchanged upon hydration by 6 Torr $\mathrm{D}_{2} \mathrm{O}$ exposure for $3 \mathrm{hrs}$, which suggests that the MOF structure is stable under low humidity. The adsorbed $\mathrm{D}_{2} \mathrm{O}$ molecules interact with $\mathrm{COO}^{-}$but do not react with the framework. The sensitivity of the carboxylate mode to hydration and dehydration was mentioned in a previous study of UiO-66 metal organic frameworks. ${ }^{74}$ The structure is maintained stable after 3-cycle absorption and desorption of water at the pressure up to 8 Torr (See Fig. S12). For each cycle, the absorption capacity for other gas (e. g. $\mathrm{CO}_{2}$ ) is decreased upon pre-adsorbing water molecules. The absorption is recovered after regeneration of frameworks by removing the water molecules upon heating in vacuum. (See Fig. S12) Because of the favorable adsorption sites, we expect that M-O-C group is vulnerable to attack by $\mathrm{D}_{2} \mathrm{O}$ molecules. Our spectroscopic results indicate that, after exposing the activated sample to 9.5 Torr $\mathrm{D}_{2} \mathrm{O}$ vapor for $50 \mathrm{~min}, \mathrm{Cu}(\mathrm{bdc})(\text { ted })_{0.5}$ is hydrolyzed by $\mathrm{D}_{2} \mathrm{O}$ molecules (Fig. 4) The direct experimental evidence is the appearance of the $v(\mathrm{O}-\mathrm{D})$ band at $2335 \mathrm{~cm}^{-1}$, which can be ascribed to C-O-D due to deuteration of $\mathrm{COO}^{-}$by the $\mathrm{D}_{2} \mathrm{O}$ molecules. This vibrational assignment is consistent with that of the OD stretching band of deuterobenzoic acid monomers calculated at $v=2333 \mathrm{~cm}^{-1}$ using AM1 semiempirical methods and $\mathrm{w}_{\text {obs }}=2331 \mathrm{~cm}^{-1}$ measured in Ar matrices. ${ }^{75}$ Another weaker $2663 \mathrm{~cm}^{-1}$ band may be associated with the $v(\mathrm{O}-\mathrm{D})$ bonded to $\mathrm{Cu}(\mathrm{II})$ ions. $^{76}$ The formation of a COOD group is also confirmed by three readily identified adsorption bands of COOD group at $1367 \mathrm{~cm}^{-1}, 1057 \mathrm{~cm}^{-1}$ and $667 \mathrm{~cm}^{-1} .1367 \mathrm{~cm}^{-1}$ band must be due to $\mathrm{C}-\mathrm{O}$ stretching mode while $1057 \mathrm{~cm}^{-1}$ band and $667 \mathrm{~cm}^{-1}$ band of a considerable breadth should be assigned to in-plane and out-of-plane OD deformation modes of dimeric carboxylic acids which are usually in the range of $675 \pm 25 \mathrm{~cm}$ ${ }^{177}$ The assignment of the bands at $1367 \mathrm{~cm}^{-1}$ and $1057 \mathrm{~cm}^{-1}$ needs to take into account the coupling between the C-O stretching and OD deformation modes. ${ }^{77}$ Another mode at $744 \mathrm{~cm}$ ${ }^{1}$ (shifting to $732 \mathrm{~cm}^{-1}$ ) occurs at the frequency characteristic of free bdc acid ligands, and is therefore attributed to the benzene trigonal ring deformation mode represented by Wilson notation 12 in the Table $1 .{ }^{54}$ Other minor bands at 1434, 1297 and $1113 \mathrm{~cm}^{-1}$ correspond to the $\mathrm{COOH}$ group formed by protonation of $\mathrm{COO}^{-}$with $\mathrm{H}_{2} \mathrm{O}$ impurities from chamber and $\mathrm{D}_{2} \mathrm{O}$ source. ${ }^{77}$ In all these measurements, the kinetic limitations are taken into account. For instance, we have monitored the $v(\mathrm{O}$ D) band as a function of time, as shown in Fig. S14. Upon introduction of 9.5 Torr $\mathrm{D}_{2} \mathrm{O}$, the intensity of the $v(\mathrm{O}-\mathrm{D})$ bands reaches saturation in $\mathrm{Cu}(\mathrm{bdc})(\text { ted })_{0.5}$ after $1 \mathrm{~h}$, and for $\mathrm{Ni}(\mathrm{bdc})(\text { ted })_{0.5}, \mathrm{Co}(\mathrm{bdc})(\text { ted })_{0.5}, 2.5 \mathrm{~h}$ and $3 \mathrm{~h}$, respectively. With this knowledge, sufficient time was given for each system to make sure that all reactions/adsorption were completed.

The Raman spectra obtained for $\mathrm{Cu}(\mathrm{bdc})(\text { ted })_{0.5}$ after hydration provide information any change associated with the local paddle wheel copper oxide cluster. As mentioned above, the doublet mode in the range of 174 to $184 \mathrm{~cm}^{-1}$ involves $\mathrm{Cu}-\mathrm{Cu}$ species and the $1003 \mathrm{~cm}^{-1}$ band can be correlated to the C-C stretching mode $v_{4}$. The variations of the doublet mode shown in Fig. 7 are consistent with a reduction of the $\mathrm{Cu}-\mathrm{Cu}$ interaction and an increase of the $\mathrm{Cu}-\mathrm{O}$ bond strength due to formation of a $\mathrm{Cu}-\mathrm{OD}$ group. ${ }^{47}$ In the high frequency region (950$1100 \mathrm{~cm}^{-1}$ range), the C-C stretching mode $v_{4}$ at $1003 \mathrm{~cm}^{-1}$ is left unchanged, indicating that the ted molecules maintain the coordination to the $\mathrm{Cu}^{2+}$ in the paddlewheel building units during the hydration process. The X-ray diffraction pattern clearly points to a structural change after hydration. All peaks shift to a higher $2 \theta$ value except for the [001], indicating that the distance between the $2 \mathrm{D} \mathrm{Cu}_{2}(\mathrm{COO})_{4}$ layers remains unchanged, which is consistent with the Raman observation that ted still coordinates to the metal sites after hydration. The twotheta position of the phases (i.e. interplanar distances) is controlled by the length of the bdc linkers and changes when these linkers are deuterated upon $\mathrm{D}_{2} \mathrm{O}$ exposure as shown in Fig. 8. From the XRD data, it is possible to conclude that the activated form is only partially hydrolyzed and is not collapsed after exposure to 9.5 Torr $\mathrm{D}_{2} \mathrm{O}$ vapor. The $\mathrm{MOF}$ structure still maintains its 3D network under 9.5 Torr vapor pressure. However, in liquid water, X-ray diffraction measurements have previously shown that the crystal structure is completely destroyed. ${ }^{78}$ Even though it is only hydrolyzed, the framework structure cannot be regenerated by evacuation of water at higher temperature up to $150^{\circ} \mathrm{C}$. (See Fig. S13)

\section{$4.2 \mathrm{Zn}(\mathrm{bdc})(\mathrm{ted})_{0.5}$}

Chen has reported that air exposed $\mathrm{Zn}(\mathrm{bdc})(\mathrm{ted})_{0.5}$ can be transformed into the two-dimensional structure MOF-2 $\left[\mathrm{Zn}(\mathrm{bdc})\left(\mathrm{H}_{2} \mathrm{O}\right)\right]$ and that MOF-2 can also be transformed back to $\mathrm{Zn}(\mathrm{bdc})(\text { ted })_{0.5}$ after adding the ted linkers to MOF-2 in DMF at $110^{\circ} \mathrm{C}$ for 2 days $^{79}$ Both $\mathrm{Zn}(\text { bdc)(ted) })_{0.5}$ and MOF-2 contain the similar square-grid $\mathrm{Zn}_{2}(\mathrm{bdc})_{2}$ composed of di-nuclear paddlewheel $\mathrm{Zn}-\mathrm{Zn}$ units bridged by bdc di-anions. However, in MOF-2, the square-grid layers are held together by hydrogen bonding between water and two adjacent paddlewheels, with the oxygen of $\mathrm{H}_{2} \mathrm{O}$ bound to the $\mathrm{Zn}$ atom and the $\mathrm{H}$ of the same $\mathrm{H}_{2} \mathrm{O}$ molecule bound to the carboxylate oxygen of the adjacent paddlewheel structure. ${ }^{80,} 81$ The XRD data of $\mathrm{Zn}(\mathrm{bdc})(\text { ted })_{0.5}$ shown in Fig. 8 clearly shows that the frameworks transform into MOF-2 after hydration. This transformation first involves the detachment of ted molecules from the frameworks, then the bonding of $\mathrm{D}_{2} \mathrm{O}$ molecules to $\mathrm{Zn}^{2+}$ apical sites of the paddle wheel building units through their oxygen atoms. An in-situ IR study confirms this process as shown below by examination of water related modes. 

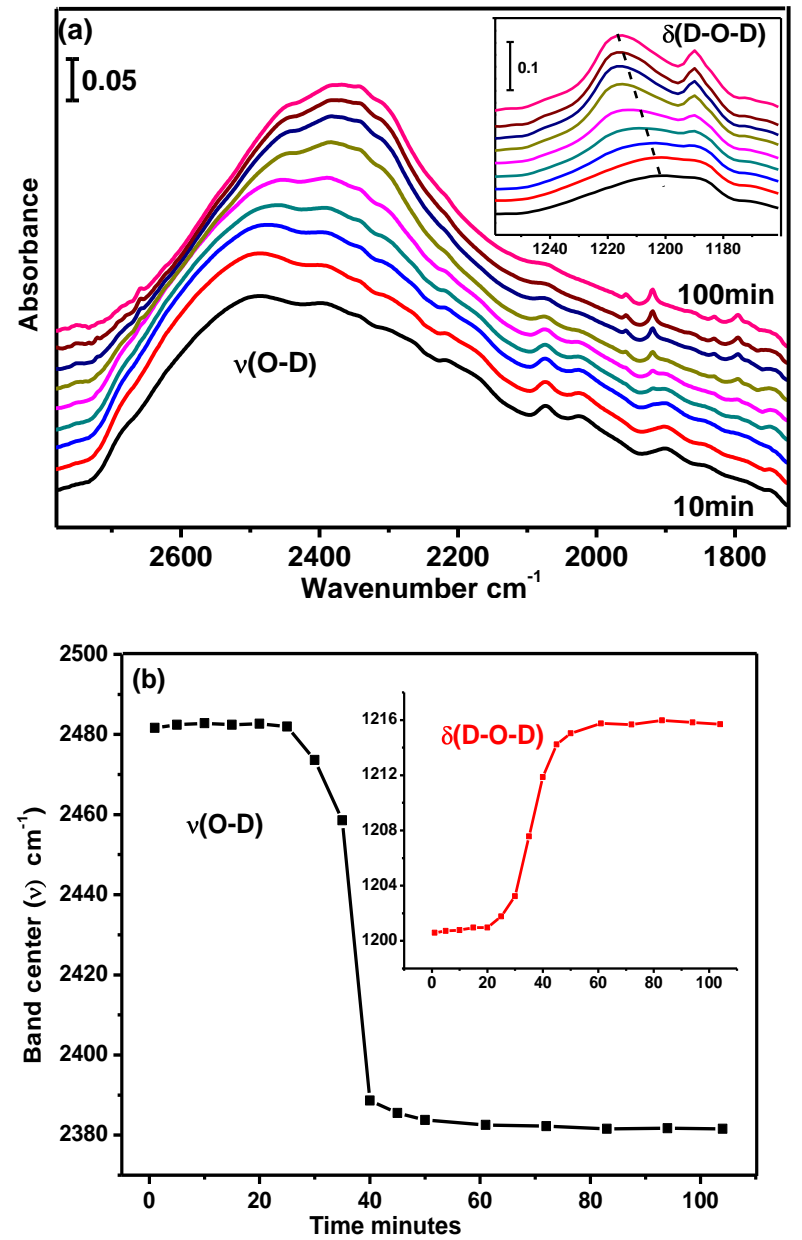

Figure 9. (a) Time dependent IR spectra of $\mathrm{D}_{2} \mathrm{O}$ adsorption into $\mathrm{Zn}(\mathrm{bdc})(\text { ted })_{0.5}$ over $100 \mathrm{~min}$, all referenced to activated $\mathrm{Zn}(\mathrm{bdc})(\text { ted })_{0.5}$ in vacuum. Inset shows bending mode $\delta(\mathrm{D}-\mathrm{O}-\mathrm{D})$ change as a function of time. From bottom to top: 10, 20, 30, 35, 40, 50, 60, 80, $100 \mathrm{~min}$. (b) v(O-D) band center change over time for $100 \mathrm{~min}$ and inset shows the bending mode change.

Instead of seeing the formation of a sharp $v(\mathrm{O}-\mathrm{D})$ band between 2700 and $2600 \mathrm{~cm}^{-1}$ by protonation reaction after exposure to $\mathrm{D}_{2} \mathrm{O}$ vapor for the $\mathrm{Cu}$, Co and Ni MOFs (See Fig. 4), there is only a broad and red-shifted $v(\mathrm{O}-\mathrm{D})$ band and a blue shift shifted $\delta$ (D-O-D) band in $\mathrm{Zn}(\mathrm{bdc})(\text { ted })_{0.5}$, which both slowly increase with time after introduction of 9.5 Torr vapor $\mathrm{D}_{2} \mathrm{O}$ as shown in Fig. 10. Initially, the $v(\mathrm{O}-\mathrm{D})$ band is centered at $2485 \mathrm{~cm}^{-1}$, characteristic of $\mathrm{D}_{2} \mathrm{O}$ adsorption band for the other three $\mathrm{M}(\mathrm{bdc})$ (ted) 0.5 compounds at 9.5 Torr (See Fig. S15). The $\delta(\mathrm{D}-\mathrm{O}-\mathrm{D})$ band is centered at $1200 \mathrm{~cm}^{-1}$ due to $\mathrm{D}_{2} \mathrm{O}$ condensation, as discussed later. After $1 \mathrm{~h}$, the $v(\mathrm{O}-\mathrm{D})$ band center gradually shifts to lower wavenumber $\left(\sim 2382 \mathrm{~cm}^{-1}\right)$ and the $\delta$ (D-O-D) band shifts to a higher wavenumber $\left(\sim 1216 \mathrm{~cm}^{-1}\right)$. These shifts for $v(\mathrm{O}-\mathrm{D})$ and $\delta(\mathrm{D}-\mathrm{O}-\mathrm{D})$ indicate that the deuterium bonding of the $\mathrm{D}_{2} \mathrm{O}$ molecules is stronger. ${ }^{82-84}$ These shift are only observed in $\mathrm{Zn}(\mathrm{bdc})(\mathrm{ted})_{0.5}$ at higher vapor pressure ( $\sim 9.5$ Torr) after $\mathrm{D}_{2} \mathrm{O}$ condensation adsorption. In other three isostructural MOFs, there are no observable shifts as a function of time. In MOF-2 structures, a bifurcated deuterium bond exists between the $\mathrm{D}_{2} \mathrm{O}$ molecules and $\mathrm{O}$ atoms of carboxylate groups and $\mathrm{O}$ atoms to the $\mathrm{Zn}$ metals in adjacent $2 \mathrm{D}$ layers. ${ }^{81}$ This type of configuration can explain the $\mathrm{D}_{2} \mathrm{O}$ vibration mode shift and the high thermal stability of hydrated $\mathrm{Zn}(\mathrm{bdc})(\mathrm{ted})_{0.5}$ in Fig. 5.

The Raman spectra of hydrated $\mathrm{Zn}(\mathrm{bdc})(\text { ted })_{0.5}$ shown in Fig. 7 can be used to determine the environment of the $\mathrm{N}$ lone pairs in the ted ligands, by utilizing the sensitivity of the $v_{4}$ C-C stretching mode the state of the $\mathrm{N}$ atom. The C-C stretching mode of ted molecules in the activated $\mathrm{Zn}(\mathrm{bdc})(\mathrm{ted})_{0.5}$ is at $1018 \mathrm{~cm}^{-1}$, and red shifts by $35 \mathrm{~cm}^{-1}$ to $983 \mathrm{~cm}^{-1}$ after hydration, which suggests that the nitrogen atom of the ted molecules is no longer connected to the metal atoms. This indicates the removal of ted molecules from the apical site of paddle wheel $\mathrm{Zn}$ clusters by $\mathrm{D}_{2} \mathrm{O}$ molecules. In the low frequency region $(100$ to $400 \mathrm{~cm}$ $\left.{ }^{1}\right)$, the doublet mode associated with the $\mathrm{Zn}-\mathrm{Zn}$ bonding persists (See Fig. 7), indicating that the paddle wheel structure remains unbroken by $\mathrm{D}_{2} \mathrm{O}$ molecules.

\section{$4.3 \mathrm{Ni}(\mathrm{bdc})(\mathrm{ted})_{0.5}$}

Powder X-ray diffraction results and Raman spectra show that the crystal structure after $\mathrm{D}_{2} \mathrm{O}$ exposure remains intact in Fig. 7 and Fig. 8. After exposing $\mathrm{Ni}(\mathrm{bdc})(\text { ted })_{0.5}$ to 9.5 Torr $\mathrm{D}_{2} \mathrm{O}$ vapor for $2.5 \mathrm{~h}$, an OD stretching band appears at $2660 \mathrm{~cm}^{-1}$ in Fig. 4. This band cannot be assigned to COOD for several reasons: (i) for the isostructural compound with $\mathrm{Cu}(\mathrm{bdc})(\mathrm{ted})_{0.5}$, in which the bdc molecules is deuterated, the $v(\mathrm{OD})$ band is observed at $2635 \mathrm{~cm}^{-1}$; (ii) the three characteristic adsorption bands for COOD in the region from 1500 to $500 \mathrm{~cm}^{-1}$, including C-O stretching, in plane and out-of-plane OD deformation at 1367,1057 , and $667 \mathrm{~cm}^{-1}$ are absent; and yet (iii) the benzene ring deformation mode $\sigma_{12}$ at $744 \mathrm{~cm}^{-1}$ indicates that $\mathrm{D}_{2} \mathrm{O}$ is definitely adsorbed into the frameworks. In the case of $\mathrm{Cu}(\mathrm{bdc})(\text { ted })_{0.5}$ shown in Fig. 10(a), this mode shifts $12 \mathrm{~cm}^{-1}$ to $756 \mathrm{~cm}^{-1}$ upon exposure to 8.5 Torr or at the beginning of the 9.5 Torr exposure. When the bdc linkers are deuterated under higher $\mathrm{D}_{2} \mathrm{O}$ vapor pressure, it shifts back to $732 \mathrm{~cm}^{-1}$ with time. In $\mathrm{Ni}(\mathrm{bdc})(\text { ted })_{0.5}$, this mode remains at high frequencies with $12 \mathrm{~cm}^{-1}$ and $8 \mathrm{~cm}^{-1}$ shifts upon $\mathrm{D}_{2} \mathrm{O}$ adsorption in all the pressure ranges (See Fig. 10 and Fig. S15). The red shift of the structure-sensitive band $v_{18 \mathrm{a}}$ at $1017 \mathrm{~cm}^{-1}$ is also different from what is observed in $\mathrm{Cu}(\mathrm{bdc})(\mathrm{ted})_{0.5}$. There is therefore no clear evidence for dissociation of the bond between the metal oxide clusters and bdc linkers in IR and Raman spectroscopy.

With regard to the $\mathrm{COO}$ vibrations and ring deformation modes described in the result section (Table 1 and Fig. 4), there are important differences in their response to water molecules that underlie their reaction characteristics, as summarized in Fig. 10. In this figure, two $\mathrm{D}_{2} \mathrm{O}$ pressures are chosen, 8 Torr and 9.5 Torr because the structures are still stable at 8 Torr, but react at 9.5 Torr. An examination of the $v_{\text {sym }}(\mathrm{COO})$ band for the four $\mathrm{M}(\mathrm{bdc})(\mathrm{ted})_{0.5}$ compounds during the time dependence experiment at 9.5 Torr in Fig. 10 reveals that there are significant differences between $\mathrm{Ni}(\mathrm{bdc})(\text { ted })_{0.5}$ and $\mathrm{Cu}(\mathrm{bdc})(\text { ted })_{0.5}$ and $\mathrm{Zn}(\mathrm{bdc})(\mathrm{ted})_{0.5}$. For $\mathrm{Cu}(\mathrm{bdc})(\mathrm{ted})_{0.5}$. At 8 Torr, the features in the adsorption spectra of Fig. 10 (a) are do minated by perturbations bands caused by incorporation of $\mathrm{D}_{2} \mathrm{O}$ molecules, similarly to what is observed at 6 Torr in Fig. 3. When the pressure is 
increased to 9 Torr, some changes occur with time in the absorption features at $1367 \mathrm{~cm}^{-1}, 667 \mathrm{~cm}^{-1}$ as well as 1434, 1297 , $1113 \mathrm{~cm}^{-1}$. The formation of these features is the result of carboxylate (COO) group reaction with $\mathrm{D}_{2} \mathrm{O}$ molecules and trace amount of $\mathrm{H}_{2} \mathrm{O}$ molecules. As discussed above, the bands at $1367 \mathrm{~cm}^{-1}$ and $667 \mathrm{~cm}^{-1}$ are due to $v(\mathrm{C}-\mathrm{O})+\delta(\mathrm{O}-\mathrm{D})$ and out of plane $\delta(C O-D)$ respectively. The 1434,1297 , and $1113 \mathrm{~cm}^{-1}$ bands are associated with the $\mathrm{COOH}$ group. After evacuation at $373 \mathrm{~K}$, the $v(\mathrm{C}=\mathrm{O})$ band in $\mathrm{Cu}(\mathrm{bdc})(\text { ted })_{0.5}$ becomes observable because it sharpens and blue shifts back to $1685 \mathrm{~cm}^{-1}$ as the deuterium bonding to oxygen atoms of $\mathrm{C}=\mathrm{O}$ group is released.

For $\mathrm{Zn}(\mathrm{bdc})(\mathrm{ted})_{0.5}$, the perturbed $\mathrm{v}_{\mathrm{sym}}(\mathrm{COO})$ band at 1361 $\mathrm{cm}^{-1}$ observed at 8.0 Torr further red shifts to $1353 \mathrm{~cm}^{-1}$ after the displacement reaction of $\mathrm{D}_{2} \mathrm{O}$ with ted linkers slowly taking place at 9.5 Torr. This shift is indicative of a stronger host-guest interaction between the carboxylate moieties and the $\mathrm{D}_{2} \mathrm{O}$ molecules. This result is consistent with the red shift of $v(\mathrm{O}-\mathrm{D})$
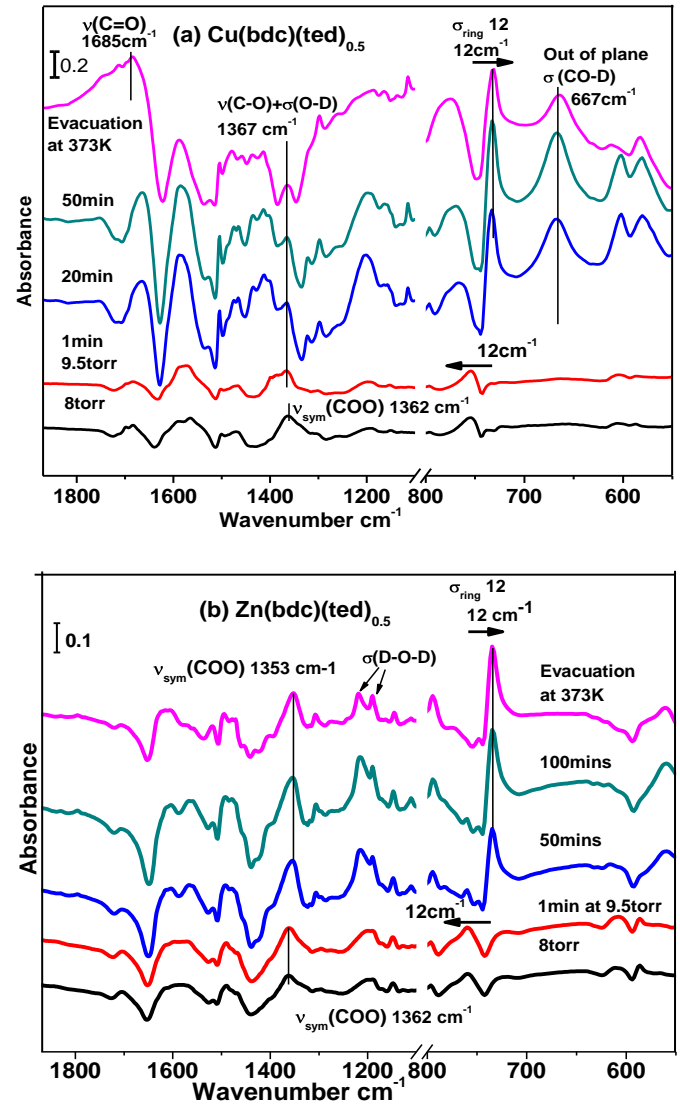

and blue shift $\delta$ (D-O-D) of the adsorbed $\mathrm{D}_{2} \mathrm{O}$ shown in Fig. 10(b). This red shift cannot be recovered by evacuating at $373 \mathrm{~K}$ because the $\mathrm{D}_{2} \mathrm{O}$ molecules remain bifurcated-deuterium bonded with the COO group shown in Fig. 5 and in Fig. 10(b) for the bending mode. In the low frequency region (600 to 700 $\mathrm{cm}^{-1}$ ), there is no evidence for the formation of out of plane OD deformation mode, confirming that the Zn-O-C group was not broken during the $\mathrm{D}_{2} \mathrm{O}$ exposure.

For $\mathrm{Ni}(\mathrm{bdc})(\text { ted })_{0.5}$, the perturbed $v_{\text {sym }}(\mathrm{COO})$ band at 1364 $\mathrm{cm}^{-1}$ at 8 Torr shifts back to a higher value of $1378 \mathrm{~cm}^{-1}$ closer to its original position and the $v_{\text {asym }}(\mathrm{COO})$ shifts from 1567 to $1574 \mathrm{~cm}^{-1}$ when the vapor pressure reaches 9.5 Torr, which indicates that the deuterium bonding between the $\mathrm{COO}$ group and the guest $\mathrm{D}_{2} \mathrm{O}$ molecules is greatly weakened. The perturbed $v_{\text {sym }}(\mathrm{COO})$ band disappears when adsorbed $\mathrm{D}_{2} \mathrm{O}$ molecules are removed by heating at $373 \mathrm{~K}$ under vacuum as shown in Fig. 10(c). However, in the case of $\mathrm{Zn}(\mathrm{bdc})(\mathrm{ted})_{0.5}$
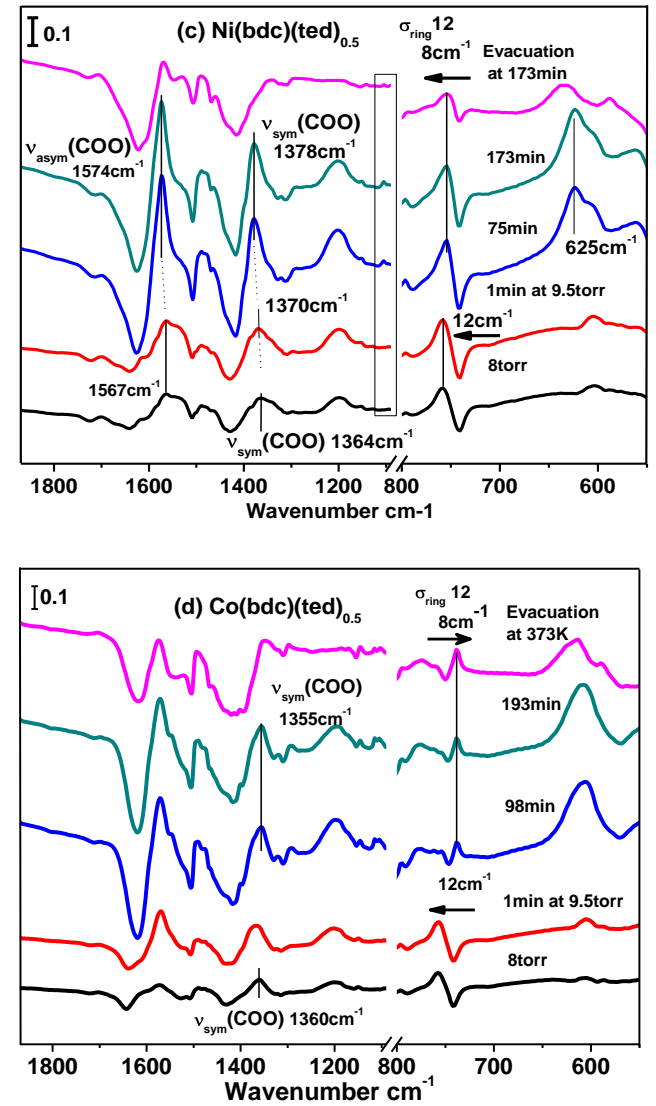

Figure 10. IR adsorption spectra of hydrated MOF during $\mathrm{D}_{2} \mathrm{O}$ exposure, reference to the activated $\mathrm{MOF}$ in a vacuum. (a) $\mathrm{Cu}(\mathrm{bdc})(\mathrm{ted})_{0.5 \text { : }}$ black, red, blue and dark green refer to after introduction of 8 Torr $\mathrm{D}_{2} \mathrm{O}$ vapor for $40 \mathrm{~min}$, after introduction of 9.5 Torr $\mathrm{D}_{2} \mathrm{O}$ vapor for 1 , 20, and $50 \mathrm{~min}$; pink, evacuation at $373 \mathrm{~K}$ for $10 \mathrm{~h}$. (b) $\mathrm{Zn}$ (bdc)(ted) $)_{0.5}$ : black, red, blue and dark green refer to after introduction of 8 Torr $\mathrm{D}_{2} \mathrm{O}$ vapor for $40 \mathrm{~min}$, after introduction of 9.5 Torr $\mathrm{D}_{2} \mathrm{O}$ vapor for $1,50,100$ min; pink, evacuation at $373 \mathrm{~K}$ for $10 \mathrm{~h}$. (c) $\mathrm{Ni}(\mathrm{bdc})(\text { ted) })_{0.5}$ : black, red, blue, and dark green refer to after introduction of 8 Torr $\mathrm{D}_{2} \mathrm{O}$ vapor for $40 \mathrm{~min}$, after introduction of $9.5 \mathrm{Torr} \mathrm{D}_{2} \mathrm{O}$ vapor for 1 , 75, and $173 \mathrm{~min}$; pink, evacuation at $373 \mathrm{~K}$ for $10 \mathrm{~h}$. (c) Co(bdc)(ted) $)_{0.5}$ : black, red, blue and dark green refer to after introduction of 8 Torr

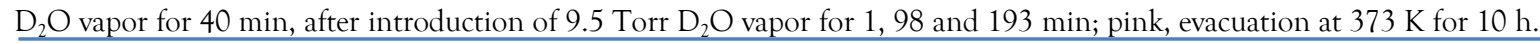

and $\mathrm{Cu}(\mathrm{bdc})(\mathrm{ted})_{0.5}$, the bands at $1352 \mathrm{~cm}^{-1}$ and $1367 \mathrm{~cm}^{-1}$, arising from the deuteration reaction, persist even after evacuation at elevated temperature. The question remains how to explain the formation of the isolated $v(\mathrm{O}-\mathrm{D})$ band at $2660 \mathrm{~cm}^{-1}$ in Fig.
4. The above IR spectroscopic results and analysis clearly show that the bdc linkers are not deuterated by $\mathrm{D}_{2} \mathrm{O}$ molecules. Similarly, the Raman and XRD results (See Fig. 7 and Fig. 8) show that the structure of $\mathrm{Ni}(\mathrm{bdc})(\text { ted })_{0.5}$ remains intact after $\mathrm{D}_{2} \mathrm{O}$ 
exposure. All the characteristic bands of $\mathrm{Ni}(\mathrm{bdc})(\text { ted })_{0.5}$ are preserved after hydration without addition of new bands in the Raman spectra. Therefore, it is more reasonable to attribute this isolated $v(\mathrm{O}-\mathrm{D})$ band to $\mathrm{D}_{2} \mathrm{O}$ molecules instead of $\mathrm{OD}$ group. The $\mathrm{D}_{2} \mathrm{O}$ molecules may coordinate to the $\mathrm{Ni}(\mathrm{II})$ ions not by breaking $\mathrm{Ni}-\mathrm{O}$ and $\mathrm{Ni}-\mathrm{N}$ bonds within the MOF structure. In support of this hypothesis, the broad band at $625 \mathrm{~cm}^{-1}$ in Fig. 4 and Fig. 10(c) is assigned to the out-of-plane (D-O-D) deformation mode. The scissor mode of such an isolated $\mathrm{D}_{2} \mathrm{O}$ would occur between in the 1050 to $1270 \mathrm{~cm}^{-1}$ region examined in Fig. 4 and Fig. 10(c): a broad peak around 1190 to $1203 \mathrm{~cm}^{-1}$ is assigned to scissor mode of adsorbed deuterated water. In addition, there is a sharp band at $1105 \mathrm{~cm}^{-1}$ that is not found at low pressure $\mathrm{D}_{2} \mathrm{O}$ vapor exposure but appears together with $v(\mathrm{O}-\mathrm{D})$ at $2660 \mathrm{~cm}^{-1}$ at higher vapor pressure in Fig. 10(c). Although such a red shift is not usually observed for H-bonded water, previous studies ${ }^{85-87}$ have shown that the $\mathrm{H}-\mathrm{O}-\mathrm{H}$ scissor frequency can be considerably red shifted in some crystalline hydrates compared to the position of $\delta(\mathrm{H}-\mathrm{O}-\mathrm{H})$ of free water molecules $\left(1594.6 \mathrm{~cm}^{-1}\right)$. For example, tetrahedral coordination of the water molecules and formation of chains $\mathrm{M}-\mathrm{O}_{\mathrm{w}}-\mathrm{M}$ in the kieserite family $\mathrm{MSO}_{4} \cdot \mathrm{H}_{2} \mathrm{O}$ causes $\delta(\mathrm{H}-\mathrm{O}-\mathrm{H})$ to shift to a lower wavenumber by $100 \mathrm{~cm}^{-1}$. 85 On the basis of these studies, we assign the $1105 \mathrm{~cm}^{-1}$ band to be isolated adsorbed $\mathrm{D}_{2} \mathrm{O}$ in $\mathrm{Ni}(\text { bdc)(ted) })_{0.5}$. This $\mathrm{D}_{2} \mathrm{O}$ is likely coordinated to the two $\mathrm{Ni}$ atoms in the dinuclear paddlewheel units. However, the degree of deuterium bonding with the $\mathrm{O}$ atoms of the $\mathrm{COO}$ group varies, leading to an apparent shift of the $v_{\mathrm{sym}}(\mathrm{COO})$ band at $1364 \mathrm{~cm}^{-1}$ toward $1380 \mathrm{~cm}^{-1}$.

\section{$4.4 \mathrm{Co}(\mathrm{bdc})(\mathrm{ted})_{0.5}$}

From the powder X-ray diffraction results (See Fig. 8), it is clear that the crystal structure of $\mathrm{Co}(\mathrm{bdc})(\mathrm{ted})_{0.5}$ is completely destroyed after exposure to 9.5 Torr $\mathrm{D}_{2} \mathrm{O}$ vapor. The framework structure cannot be recovered after annealing in vacuum up to $150{ }^{\circ} \mathrm{C}$ to remove adsorbed water. (See Fig. S13) To understand the dissociation of the MOFs structure, we examine the evolution of the spectroscopic data. As for $\mathrm{Ni}($ bdc $)(\text { ted })_{0.5}$, there are no bands associated with the COOD group in the region from 1500 to $500 \mathrm{~cm}^{-1}$ in the IR adsorption spectra of hydrated Co(bdc)(ted) $)_{0.5}$ in Fig. 4. Moreover, there is a red shift of $v_{18 a}$ from $1017 \mathrm{~cm}^{-1}$ to $1013 \mathrm{~cm}^{-1}$. These spectroscopic results indicate that there is no hydrolysis reaction with $\mathrm{Co}-\mathrm{O}-\mathrm{C}$ during $\mathrm{D}_{2} \mathrm{O}$ vapor exposure. The bdc linkers are still coordinated with $\mathrm{Co}(\mathrm{II})$ ions by COO group. However, the loss of the $v_{4}$ mode and doublet mode at 158 and $167 \mathrm{~cm}^{-1}$ in the Raman spectra of Fig. 7 indicates that the coordinated ted linkers disappear and the $\mathrm{Co}-\mathrm{Co}$ structure is affected by hydration. By comparing Fig.10 (b) and (d), we find that the $\mathrm{Co}(\mathrm{bdc})(\text { ted) })_{0.5}$ and $\mathrm{Zn}(\mathrm{bdc})(\mathrm{ted})_{0.5}$ exhibit similar shifts of $v_{\mathrm{sym}}(\mathrm{COO})$ and ring deformation bands upon $\mathrm{D}_{2} \mathrm{O}$ inclusion. For $\mathrm{Co}(\mathrm{bdc})(\text { ted })_{0.5}$, the $v_{\text {sym }}(\mathrm{COO})$ mode at $1360 \mathrm{~cm}^{-1}$ red shifts a little to a lower wavenumber of $1355 \mathrm{~cm}^{-1}$. The ring deformation band $\sigma_{12}$ blue shifts by $12 \mathrm{~cm}^{-1}$ at 8 Torr but red shifts by $8 \mathrm{~cm}^{-1}$ at 9.5 Torr under hydration. These changes in the $\mathrm{COO}$ modes are similar in the spectra of hydrated $\mathrm{Co}(\mathrm{bdc})(\mathrm{ted})_{0.5}$ and $\mathrm{Zn}(\mathrm{bdc})(\text { ted })_{0.5}$. However, the $\mathrm{D}_{2} \mathrm{O}$ bands including $v(\mathrm{O}-\mathrm{D})$ and $\delta(\mathrm{D}-\mathrm{O}-\mathrm{D})$ behave differently for these two MOFs. The shift of $v(O-D)$ and $\delta(D-O-D)$ in
$\mathrm{Zn}(\mathrm{bdc})(\mathrm{ted})_{0.5}$ mentioned before is result of displacement of ted molecules by $\mathrm{D}_{2} \mathrm{O}$. For $\mathrm{Co}(\mathrm{bdc})(\text { ted })_{0.5}$, a isolated $v(\mathrm{O}-\mathrm{D})$ band is identified at $2356 \mathrm{~cm}^{-1}$ after hydration shown in Fig. 4 and remains after evacuation at $373 \mathrm{~K}$ for $10 \mathrm{~h}$ as shown in Fig. 5. We therefore conclude that $\mathrm{D}_{2} \mathrm{O}$ molecules attack the Co-N bond and replace the ted linker to bond the apical Co(II) site. However, unlike the $\mathrm{D}_{2} \mathrm{O}$ molecules in hydrated $\mathrm{Zn}(\mathrm{bdc})(\text { ted })_{0.5}$ that have a bifurcated-deuterium bonding with $\mathrm{Zn}_{2}(\mathrm{bdc})_{2}$ layers, the $\mathrm{D}_{2} \mathrm{O}$ molecules in hydrated $\mathrm{Co}(\mathrm{bdc})(\text { ted })_{0.5}$ are coordinated to $\mathrm{Co}(\mathrm{II})$ ions via one oxygen atom only. As a result, the paddle wheel $\mathrm{Co}_{2}(\mathrm{COO})_{4}$ is distorted and the Co-Co interaction is removed. This is why the doublet involving Co-Co in Raman spectra of Fig. 8 disappears in hydrated $\mathrm{Co}(\mathrm{bdc})(\mathrm{ted})_{0.5}$ and the crystal structure collapses after hydration. Consequently, we ascribe the broad band at $612 \mathrm{~cm}^{-1}$ in Fig. 4 and Fig. 10(d) to the out-of-plane (D-O-D) deformation mode.

\section{Discussion}

\subsection{Condensation}

To study the water adsorption behavior, we performed the pressure dependence measurement of $\mathrm{D}_{2} \mathrm{O}$ vapor adsorption into $\mathrm{M}(\mathrm{bdc})(\mathrm{ted})_{0.5}$. The spectra were recorded as a function of vapor pressure from $\sim 1$ Torr to $\sim 9.5$ Torr with 40 min to equilibrate at each pressure. Fig. 11 shows 1$)$ the spectra upon $\mathrm{D}_{2} \mathrm{O}$ adsorption into $\mathrm{Cu}(\mathrm{bdc})(\text { ted })_{0.5}$ in the range of the $v(\mathrm{O}-\mathrm{D})$ and $\sigma(\mathrm{D}-\mathrm{O}-\mathrm{D})$ modes and 2) the integrated areas of these two modes as a function of pressure up to 9.5 Torr. In the low pressure range (up to 8 Torr), the integrated areas of both $v(\mathrm{O}-\mathrm{D})$ and $\sigma(\mathrm{D}-\mathrm{O}-\mathrm{D})$ modes increase almost linearly with pressure. A steep increase occurs around 8.5 Torr, which is assumed to be the result of $\mathrm{D}_{2} \mathrm{O}$ molecules condensation in the pore. The inset in Fig. 11(a) provides spectroscopic evidence for condensation by the shift of $\sigma(D-O-D)$ with increasing pressure from $1189 \mathrm{~cm}^{-1}$ to $1200 \mathrm{~cm}^{-1}$, which is the typical frequency of $\sigma(\mathrm{D}-\mathrm{O}-\mathrm{D})$ in the liquid $\mathrm{D}_{2} \mathrm{O} .{ }^{84}$ In Fig. 12, we can also see that $\mathrm{D}_{2} \mathrm{O}$ adsorption increases as the temperature is lowered, as is expected for physisorption in micropores.

Fig. S15 presents the infrared absorption spectra for $\mathrm{M}(\mathrm{bdc})(\text { ted })_{0.5}[\mathrm{M}=\mathrm{Zn}, \mathrm{Ni}, \mathrm{Co}]$ as a function of $\mathrm{D}_{2} \mathrm{O}$ pressure. All of them show the same linear increase in low pressure region and a steep increase at 8.5 Torr as observed in $\mathrm{Cu}(\mathrm{bdc})(\text { ted })_{0.5}$; indicating that the physical $\mathrm{D}_{2} \mathrm{O}$ adsorption in the $\mathrm{M}(\mathrm{bdc})(\mathrm{ted})_{0.5}$ series is independent of the central metal ions. 

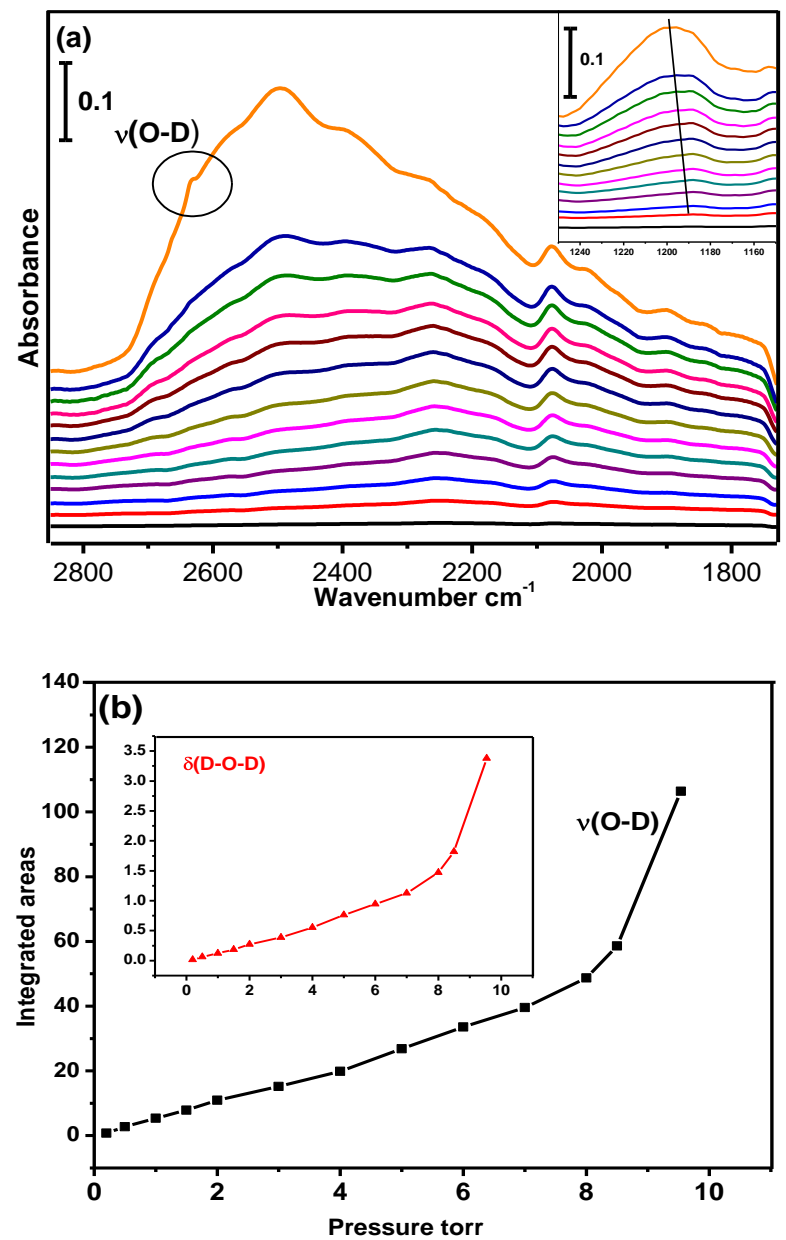

Figure 11. (a), IR spectra of $\mathrm{D}_{2} \mathrm{O}$ adsorption into $\mathrm{Cu}(\mathrm{bdc})(\text { ted })_{0.5}$ as a function of pressure from bottom to top:200 mTorr, 500 mTorr, 800 mTorr, 1, 2, 3, 4, 5, 6, 7, 8, 8.5, 9.5 Torr. Inset shows the bending mode region from 1150 to $1250 \mathrm{~cm}^{-1}$. All referenced to activated MOF in vacuum. (b), integrated areas of stretching band in the region of $2736-1753 \mathrm{~cm}^{-1}$ as a function of vapor pressure. Inset shows integrated areas of bending mode as a function of pressure.

In all four compounds, we see that the reaction of $\mathrm{D}_{2} \mathrm{O}$ with the paddle wheel structure is initiated upon condensation of $\mathrm{D}_{2} \mathrm{O}$ inside the pores, initiates reaction as shown in Fig. 11 and Fig. S15. For example, in $\mathrm{Cu}(\mathrm{bdc})(\mathrm{ted})_{0.5}$, the $\mathrm{Cu}-\mathrm{O}-\mathrm{C}$ group is hydrolyzed into $\mathrm{Cu}-\mathrm{OD}$ and $\mathrm{C}-\mathrm{OD}$ as $\mathrm{D}_{2} \mathrm{O}$ is dissociated,. This reaction does not take place at low $\mathrm{D}_{2} \mathrm{O}$ vapor pressure. In this low pressure regime, the $\mathrm{D}_{2} \mathrm{O}$ molecules do not induce decomposition of frameworks, although the MOF structure is perturbed, as evidenced by strong variations in the MOF phonon bands. The reaction of $\mathrm{D}_{2} \mathrm{O}$ with the metal oxide bonds in the $\mathrm{MOF}$ is reminiscent of water adsorption on metal oxide surfaces, such as $\mathrm{MgO}, \mathrm{ZnO}$, and $\mathrm{NiO}$, for which there are theoretical predictions of strong dependence of the dissociation barrier on water coverage. ${ }^{88-90}$ A First-principles molecular-dynamics simulation has predicted that an isolated water molecule on $\mathrm{MgO}[100]$ surface is not sufficient to induce dissociation, only bonding molecularly through one hydrogen of the water molecule to a surface oxygen. Above 1/2 ML coverage, the dissocia- tion of waters occurs and a mixture of molecular and dissociated water molecules is observed at $2 / 3 \mathrm{ML}$ and 1 monolayer coverage. This can be explained by the fact that a hydrogen bond is formed between water molecules and that this hydrogen bond weakens the $\mathrm{OH}$ bond in neighboring molecules, lowering the barrier for water dissociation. The same situation takes place for adsorbed $\mathrm{D}_{2} \mathrm{O}$ molecules in $\mathrm{Cu}(\mathrm{bdc})(\mathrm{ted})_{0.5} \mathrm{com}$ pounds: the condensation of $\mathrm{D}_{2} \mathrm{O}$ molecules into the framework weakens the OD bonds and induces hydrolysis with the Cu-O-C group. (See Fig.11) The temperature dependence experiments confirm this picture in which condensation is critical for reaction. At higher temperature of $50{ }^{\circ} \mathrm{C}$ and $40{ }^{\circ} \mathrm{C}$, the framework is stable to 13 Torr $\mathrm{D}_{2} \mathrm{O}$ vapor because condensation does not occur. When the temperature is decreased to 35 ${ }^{\circ} \mathrm{C}$, the $\mathrm{D}_{2} \mathrm{O}$ molecules begin to react with frameworks as evidenced by the appearance of the $v(\mathrm{O}-\mathrm{D})$ band at $2635 \mathrm{~cm}^{-1}$ and $2663 \mathrm{~cm}^{-1}$ that confirms a deuteration reaction of the bdc linkers with the $\mathrm{D}_{2} \mathrm{O}$ molecules. At the same time, the center of $\mathrm{D}_{2} \mathrm{O}$ bending mode shifts to $1200 \mathrm{~cm}^{-1}$ (see inset $\mathrm{b}$ of Fig. 12), confirming that $\mathrm{D}_{2} \mathrm{O}$ molecules are condensing into the frameworks at $35^{\circ} \mathrm{C}$.

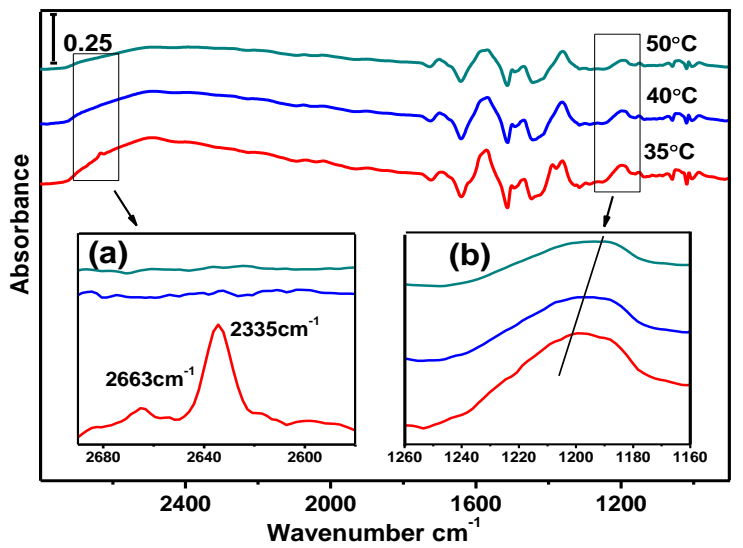

Figure 12. IR spectra of $\mathrm{D}_{2} \mathrm{O}$ adsorption into $\mathrm{Cu}(\mathrm{bdc})(\text { ted) })_{0.5}$ with temperature decreasing from $50^{\circ} \mathrm{C}, 40{ }^{\circ} \mathrm{C}$ to $35^{\circ} \mathrm{C}$ at constant pressure of 13 Torr $\mathrm{D}_{2} \mathrm{O}$ vapor, referenced to activated MOF in vacuum. Inset a and $\mathrm{b}$ shows stretching mode region and bending mode region.

\subsection{Effects of Metal Ions on Stability and Reaction Pathway:}

Huang et al. first reported that exposure of MOF-5 to water resulted in possible hydrolysis of the materials and the formation of terephthalic acid $\left(\mathrm{H}_{2} \mathrm{bdc}\right){ }^{20}$ Later, Greathouse and Allendorf used empirical force fields and molecular dynamics to predict that this reaction is initiated by a direct attack of MOF-5 by water molecules. ${ }^{21}$ The weak bonds between $\mathrm{Zn}$ and $\mathrm{O}$ atoms in MOF-5 can be broken when interacting with water molecules. Low et al. used a quantum mechanical to model the hydrolysis reaction of water with metal oxide clusters, showing that it involved the breaking and reforming of bonds in different types of metal organic frameworks depending on the specific secondary building units (SBUs). ${ }^{18}$ The proton of water molecules can attack the oxygen of metal oxide cluster when the carboxylate opens up a coordination site on the metal for the 
water molecules. Later, Han used a reactive force field (ReaxFF) approach to perform a detailed study of hydrolysis of MOF-5 and found a direct water interaction with $\mathrm{ZnO}_{4}$ tetrahedron in framework induces cleavage of $\mathrm{Zn}-\mathrm{O}$ bonds and dissociation of $\mathrm{H}_{2} \mathrm{O}$ molecules of into $\mathrm{OH}$ and $\mathrm{H}$. The resulting $\mathrm{OH}$ forms a chemical bond with $\mathrm{Zn}$, and the proton is attached to the oxygen of the bdc moiety. ${ }^{23}$

From our experimental results of the four isostructural compounds $\mathrm{M}(\mathrm{bdc})(\mathrm{ted})_{0.5}[\mathrm{M}=\mathrm{Cu}, \mathrm{Zn}, \mathrm{Ni}$, and $\mathrm{Co}]$ with paddlewheel dinuclear metal clusters, we find that both the initial decomposition pathway and the stability of the MOF frameworks with respect to reaction with $\mathrm{D}_{2} \mathrm{O}$ molecules are dependent on the central metal ions. For $\mathrm{Cu}(\mathrm{bdc})(\text { ted })_{0.5}$, the hydrolysis reaction of $\mathrm{D}_{2} \mathrm{O}$ molecules with metal oxide clusters $\mathrm{Cu}-\mathrm{O}-\mathrm{C}$ can be confirmed by our in-situ IR spectroscopy measurements under high humidity conditions (48\%). However, the hydrolysis decomposition mechanism does not hold true in all isostructural compounds of $\mathrm{M}(\mathrm{bdc})(\mathrm{ted})_{0.5}$ under the same conditions. For $\mathrm{Zn}(\mathrm{bdc})(\mathrm{ted})_{0.5}$, the $\mathrm{Zn}-\mathrm{N}$ bonds are broken by reaction with $\mathrm{D}_{2} \mathrm{O}$ molecules so that ted molecules are released from the apical sites of the paddlewheel dinuclear $\mathrm{Zn}^{2+}$ clusters and the $\mathrm{D}_{2} \mathrm{O}$ molecules bond to $\mathrm{Zn}$ SBUs. In contrast, the Cu-N group in $\mathrm{Cu}(\mathrm{bdc})(\mathrm{ted})_{0.5}$ structure is less susceptible to displacement by incoming water molecules because the overall formation (stability) constant of its amine complex in aqueous solution. Both $\mathrm{Cu}(\mathrm{II})$ and $\mathrm{Zn}(\mathrm{II})$ form amine complexes, $\mathrm{Cu}\left(\mathrm{NH}_{3}\right)_{4}{ }^{2+}$ and $\mathrm{Zn}\left(\mathrm{NH}_{3}\right)_{4}{ }^{2+}$, in an ammonia medium, although with very different stability constants: $1.1 \quad 10^{13}$ and $2.8 \quad 10^{9}$, respectively. ${ }^{91}$

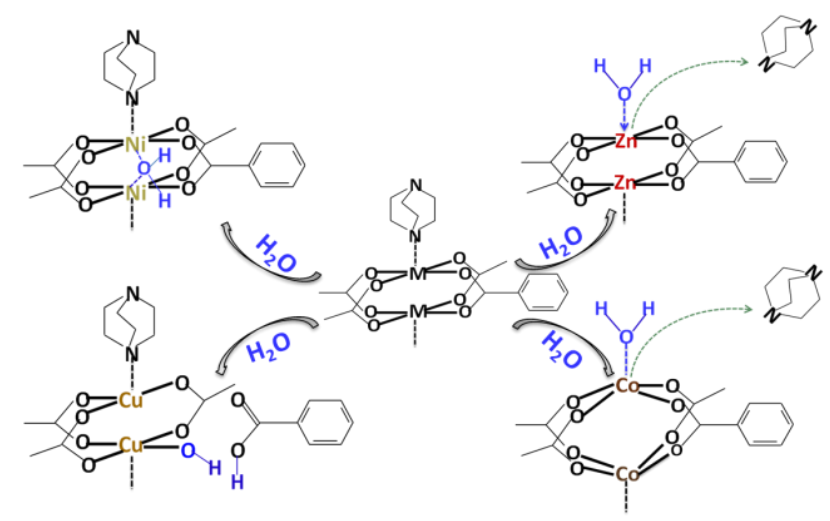

Figure 13. Schematic illustration of decomposition pathway of $\mathrm{M}(\mathrm{bdc})(\text { ted })_{0.5}[\mathrm{M}=\mathrm{Cu}, \mathrm{Zn}, \mathrm{Ni}, \mathrm{Co}]$ reaction with $\mathrm{D}_{2} \mathrm{O}$ molecules.

$\mathrm{Ni}(\mathrm{bdc})(\text { ted })_{0.5}$ is more stable in $\mathrm{D}_{2} \mathrm{O}$ vapor than $\mathrm{Cu}(\mathrm{bdc})(\text { ted })_{0.5}$ and $\mathrm{Zn}(\mathrm{bdc})(\text { ted })_{0.5}$, at least under the same condition of 9.5 Torr vapor exposure at RT as shown from XRD measurements in Fig. 8. The Raman spectra after $\mathrm{D}_{2} \mathrm{O}$ exposure also confirm that the metal-oxide paddle-wheel did not break down. The relatively higher stability of $\mathrm{Ni}(\mathrm{bdc})(\text { ted })_{0.5}$ against hydrolysis reaction is consistent with a model of water interaction with the surface of rocksalt $\mathrm{NiO}$ (100). Indeed, there is a consensus both from experimental investigations and theoretical calculations that water adsorbs molecularly on $\mathrm{NiO}(100)$ surfaces and that a dissociation reaction can only take place at defect sites. ${ }^{92-95}$ Simpson's theoretical calculation by using the semi-empirical SCFMO method MSINDO shows that water dissociation is unlikely on the planar surface of $\mathrm{NiO}(100)$ and the associated activation energy for dissociation is high due to the rigidity of the $\mathrm{NiO}(100)$ lattice which prevents water molecule from adopting a stable transition state, ${ }^{96}$ suggesting by analogy that $\mathrm{Ni}(\mathrm{bdc})(\text { ted })_{0.5}$ is more stable in water vapor. These conclusions are also supported by considering the metal-oxygen strength from the dissociation energy for diatomic molecules: $\mathrm{Zn}-\mathrm{O}(<250.4 \mathrm{kj} / \mathrm{mol}), \quad \mathrm{Cu}-\mathrm{O}(\sim 287.4 \mathrm{kj} / \mathrm{mol}), \quad \mathrm{Ni}-\mathrm{O}(\sim 366$ $\mathrm{kj} / \mathrm{mol}), \mathrm{Co}-\mathrm{O}(\sim 397.4 \mathrm{kj} / \mathrm{mol}){ }^{97}$ It is therefore expected that $\mathrm{Ni}(\mathrm{bdc})(\text { ted })_{0.5}$ is more stable than $\mathrm{Cu}(\mathrm{bdc})(\text { ted })_{0.5}$ to hydrolysis reaction with water molecules. The stability of the $\mathrm{Ni}-\mathrm{N}$ group of ted linkers to a displacement reaction by incoming water molecules can be also justified by the overall formation (stability) constant of the hexaaminemetal complex in aqueous solution. The constant of $\mathrm{Ni}\left(\mathrm{NH}_{3}\right)_{6}{ }^{2+}$ is $2.0 \quad 10^{8}$, much higher than that of $\mathrm{Co}\left(\mathrm{NH}_{3}\right)_{6}{ }^{2+} 2.0 \quad 10^{4} .{ }^{91}$ It is experimentally observed that cobalt(II) nitrate hydroxide precipitates in an ammonia medium rather than forming amine complexes, ${ }^{98}$ which is consistent with our observation that $\mathrm{Co}-\mathrm{N}$ in $\mathrm{Co}(\mathrm{bdc})(\mathrm{ted})_{0.5}$ is easily displaced by $\mathrm{D}_{2} \mathrm{O}$ molecules. The displacement reaction induces the $\mathrm{Co}(\mathrm{bdc})(\text { ted })_{0.5}$ structure collapse under $\mathrm{D}_{2} \mathrm{O}$ vapor. However, the high $\mathrm{Co}-\mathrm{O}$ bond strength $(397.4 \mathrm{kj} / \mathrm{mol})$ prevents the bdc moieties from being deuterated by $\mathrm{D}_{2} \mathrm{O}$ molecules. Fig. 13 presents a schematic illustration of the initial decomposition pathway of $\mathrm{M}(\mathrm{bdc})(\mathrm{ted})_{0.5}[\mathrm{M}=\mathrm{Cu}, \mathrm{Zn}, \mathrm{Ni}, \mathrm{Co}]$ reaction with $\mathrm{D}_{2} \mathrm{O}$ molecules at 9.5 Torr. For $\mathrm{Ni}($ bdc $)(\text { ted })_{0.5}$, if we slightly increase the pressure to 9.7 Torr, condensation occurs the framework structure is broken (See Fig. S16). This result is consistent with Liang's study that shows that the crystal structure of $\mathrm{Ni}(\mathrm{bdc})(\text { ted })_{0.5}$ partially collapses at high humidity levels (e g., 60\%) at RT. ${ }^{64}$ However, the order of stability of $\mathrm{M}(\mathrm{bdc})(\text { ted })_{0.5}$ series does not completely follow the empirical Irving-Williams sequence for relative stabilities of metal complexes (i.e., " $\left.\mathrm{Mn}^{2+}<\mathrm{Fe}^{2+}<\mathrm{Co}^{2+}<\mathrm{Ni}^{2+}<\mathrm{Cu}^{2+}>\mathrm{Zn}^{2+"}\right) .{ }^{99}$

\subsection{Theoretical investigation}

Aiming to understand how water can influence the $\mathrm{M}(\mathrm{bdc})(\mathrm{ted})_{0.5}$ structure, we performed vdW-DF simulations. We followed the scheme shown in Fig. 14, where water molecules replaced the ted group.

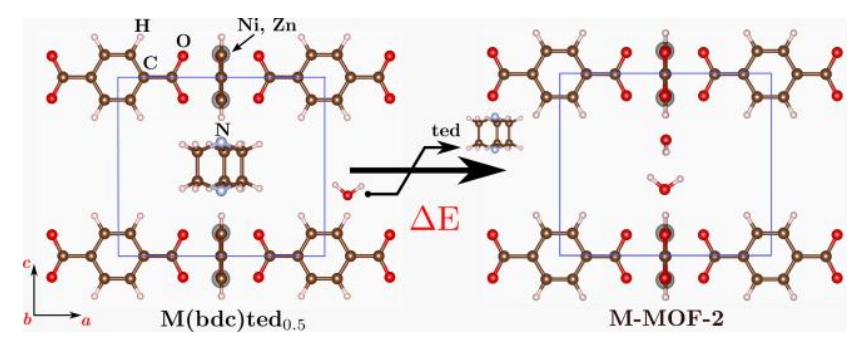

Figure 14. Scheme adopted for water insertion in $2 \cdot \mathrm{M}(\mathrm{bdc})(\text { ted })_{0.5}$ $[\mathrm{M}=\mathrm{Zn}, \mathrm{Ni}]$, where the ted group has been substituted by some water molecules.

The relevant physical quantity governing the hydration of $\mathrm{M}(\mathrm{bdc})(\mathrm{ted})_{0.5}$ is $\Delta \mathrm{E}$ (See Fig. 14), which represents the energy 
necessary to extract and replace the ted unit with water molecules:

$$
\begin{gathered}
\Delta E=\left[E\left(2 \cdot M(b c d) \operatorname{ted}_{0.5}\right)+\mathbf{n E}(\mathrm{W})-E\left(M-M O F-2 \mathbf{n H}_{2} \mathrm{O}\right)-\right. \\
1 / 2 \mathrm{E}(\mathrm{ted})]
\end{gathered}
$$

where $\mathbf{n}$ is the number of water molecules introduced. M-MOF$2 \mathbf{n H}_{2} \mathrm{O}$ is the $\mathrm{M}(\mathrm{bdc})(\text { ted })_{0.5}$ where ted was replaced by $\mathbf{n}$ water molecules. Initially, only two water molecules (per cell) were introduced, coordinating the bare metal sites $[\mathrm{M}=\mathrm{Zn}$ and $\mathrm{Ni}]$. The number of water molecules (per structure) was then progressively increased up to 10 molecules (per cell, 5 per $\mathrm{M}(\mathrm{bdc})(\text { ted })_{0.5}$ unit), simulating the effect of increasing water pressure. Fig. 15 shows the oxygen local environment of the metal atoms $[\mathrm{M}=\mathrm{Zn}$ and $\mathrm{Ni}]$ available in the $2 \cdot \mathrm{M}(\mathrm{bdc})(\mathrm{ted})_{0.5}$ for $\mathrm{H}$-bridging with incoming water molecules.

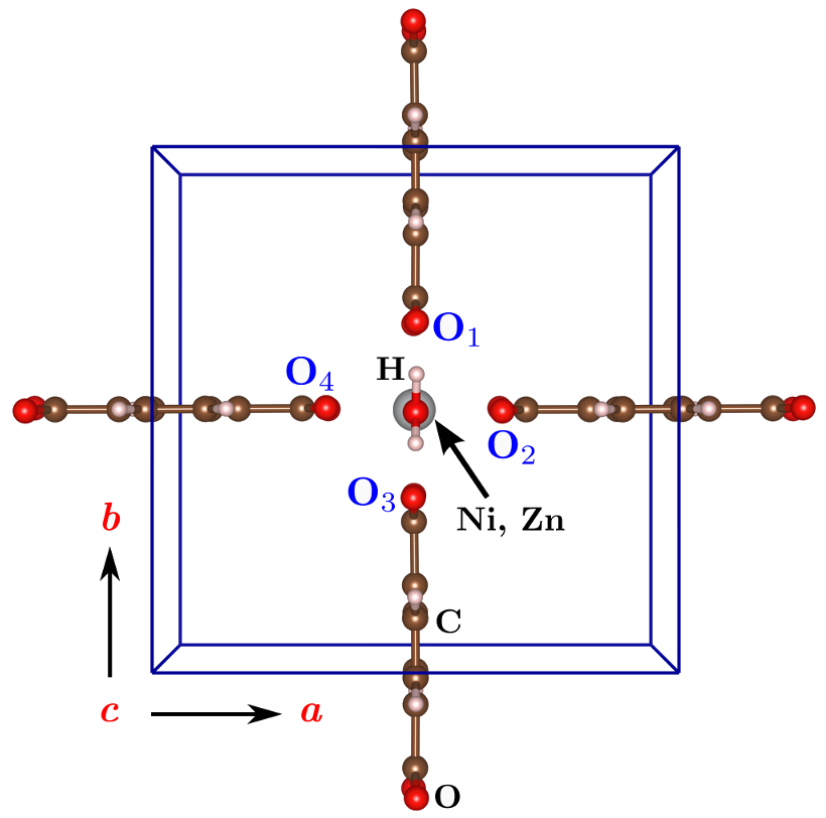

Figure 15. View along the $\left[\begin{array}{lll}0 & 0 & 1\end{array}\right]$ plane of the $\mathrm{M}(\mathrm{bdc})(\mathrm{ted})_{0.5}(\mathrm{M}$ MOF-2) [M=Zn and Ni] once the ted unit has been replaced by two water molecules (here only one water molecule is shown, see Figure 14). Labels $\mathrm{O}_{1}, \mathrm{O}_{2}, \mathrm{O}_{3}$, and $\mathrm{O}_{4}$ show the local environment of the metal sites $\mathrm{Ni}, \mathrm{Zn}$, on which water molecules were progressively adsorbed, simulating the effect of increasing water pressure

Table 2. Computed $\Delta \mathrm{E}$ and $\Delta \mathrm{E}_{\mathrm{MOF}-2}\left(\mathrm{~kJ} \mathrm{~mol}^{-1}\right.$ cell $\left.^{-1}\right)$ as a function of the number of water molecules per cell. $|\Delta|$ is the difference between $\Delta \mathrm{E}$ (or $\Delta \mathrm{E}_{\mathrm{MOF}-2}$ ) for $\mathrm{Zn}$ and $\mathrm{Ni}$.

\begin{tabular}{ccccccc}
\hline \multirow{2}{*}{$\begin{array}{c}\text { No. } \\
\mathrm{H}_{2} \mathrm{O} / \text { cell }\end{array}$} & \multicolumn{3}{c}{$\Delta \mathrm{E}$} & \multicolumn{3}{c}{$\Delta \mathrm{E}_{\text {MOF-2 }}$} \\
\cline { 2 - 7 } & $\mathrm{Zn}$ & $\mathrm{Ni}$ & $|\Delta|$ & $\mathrm{Zn}$ & $\mathrm{Ni}$ & $|\Delta|$ \\
\hline 2 & +43.1 & +85.5 & 42.4 & 0.0 & 0.0 & 0.0 \\
4 & -5.3 & +4.2 & 9.5 & -53.6 & -77.1 & 23.5 \\
6 & -21.4 & -17.1 & 4.3 & -53.7 & -68.4 & 14.7 \\
8 & -31.3 & -24.0 & 7.3 & -56.1 & -52.4 & 3.7 \\
10 & -35.0 & -45.2 & 10.2 & -54.5 & -55.3 & 0.8 \\
\hline
\end{tabular}

At first glance, the $\Delta E$ 's values calculated for $\mathrm{Zn}$ and $\mathrm{Ni}$ follow the trend found experimentally, i.e. water seems less reactive with $\mathrm{Ni}(\mathrm{bdc})(\mathrm{ted})_{0.5}$. On the other hand, the hydration of $\mathrm{Zn}(\mathrm{bdc})(\text { ted })_{0.5}$ is a highly spontaneous process even when only a few water molecules (4 molecules, See Table 2) are introduced in the unit cell. Experimentally, the sorption capacity of $\mathrm{Zn}$ (bdc)(ted) 0.5 was estimated at approximately 2.5 molecules per unit cell, which is in excellent agreement with results of water vapor sorption isotherm measurement. ${ }^{62}$ Here the driving force is the formation of strong H-bonds between water molecules, which stabilizes the coordination of $\mathrm{Zn}$ metal sites. Although strong H-bonding networks also take place in the case of $\mathrm{Ni}(\text { bdc)(ted) })_{0.5}$, this does not decrease the $\Delta \mathrm{E}$ to negative values, hence explaining our experimental findings. Alternatively we can imagine the hydration of the M-MOF structure (where this latter is formed when $\mathrm{n}=2$ in Eq. 1):

$$
\Delta \mathrm{E}_{\mathrm{MOF}-2}=\left[\mathrm{E}(\mathrm{M}-\mathrm{MOF}-2)+\mathbf{n E}(\mathrm{W})-\mathrm{E}\left(\mathrm{M}-\mathrm{MOF}-2 \mathbf{n H}_{2} \mathrm{O}\right)\right]
$$

The hydration of both $\mathrm{Zn}$ - and Ni-MOF-2 is a spontaneous process, and this is slightly more favorable for Ni. For situations of high loading $(\mathrm{n}=10) \Delta \mathrm{E}_{\mathrm{MOF}-2}$ reaches a steady value of $55 \mathrm{~kJ}$ mol $^{-1}$ cell $^{-1}$ (see Table 2). However, $\Delta \mathrm{E}_{\mathrm{MOF}-2}$ measures only the strength of the hydrogen-bond network acting between water molecules.

\section{Conclusion}

In summary, we have experimentally investigated the interaction of $\mathrm{D}_{2} \mathrm{O}$ with prototypical metal organic frameworks $\mathrm{M}(\mathrm{bdc})(\text { ted })_{0.5}[\mathrm{M}=\mathrm{Cu}, \mathrm{Zn}, \mathrm{Ni}$ and $\mathrm{Co}]$. We find that the structural stability of $\mathrm{M}(\mathrm{bdc})(\mathrm{ted})_{0.5}$ compounds is determined by the water content inside the MOF. At lower loading, the structures remain intact. At higher loading, due to water condensation, the structures can decompose by reaction of water with the paddle wheel metal cluster and organic linkers, as observed by in-situ IR spectroscopy and ex-situ Raman scattering. Condensation was determined through pressure and temperature dependence studies. We also find that the initial decomposition pathways sensitively depend on the central metal ions: For $\mathrm{Cu}(\mathrm{bdc})(\mathrm{ted})_{0.5}$, a hydrolysis reaction of water molecules with $\mathrm{Cu}-\mathrm{O}-\mathrm{C}$ group induces the paddle wheel structural decomposition. For $\mathrm{Zn}(\mathrm{bdc})(\text { ted })_{0.5}$ and $\mathrm{Co}(\mathrm{bdc})(\text { ted })_{0.5}$, the water molecules replace ted pillars and bond to the apical sites of paddle wheel $\mathrm{Zn}_{2}(\mathrm{COO})_{4}$ and $\mathrm{Co}_{2}(\mathrm{COO})_{4}$. Finally, we find that the overall stability of isostructural MOFs $\mathrm{M}(\mathrm{bdc})(\mathrm{ted})_{0.5}$ follows the order of $\mathrm{Cu}-\mathrm{MOF}<\mathrm{Ni}-\mathrm{MOF}>\mathrm{Zn}-\mathrm{MOF}>\mathrm{Co}-\mathrm{MOF}$ and this order can be correlated with bond dissociation energy of diatomic molecules metal-oxygen and overall formation(stability) constants of metal amine complexes. The findings of this work are supported by first-principles calculations, providing the information necessary for determining operating conditions of this class of MOFs with a paddle wheel secondary building unit in harsh environments and for guiding the development of more robust units.

\section{ASSOCIATED CONTENT}


Supporting Information. $\mathrm{M}(\mathrm{bdc})(\mathrm{ted})_{0.5}$ structure description, The IR adsorption of $\mathrm{M}(\mathrm{bdc})(\mathrm{ted})_{0.5}[\mathrm{M}=\mathrm{Zn}, \mathrm{Ni}$ and $\mathrm{Co}]$, Raman spectra of activated $\mathrm{M}(\mathrm{bdc})(\mathrm{ted})_{0.5}[\mathrm{M}=\mathrm{Zn}, \mathrm{Ni}$ and $\mathrm{Co}]$ and hydrated $\mathrm{M}(\mathrm{bdc})(\mathrm{ted})_{0.5}$, Raman spectra of $\mathrm{M}(\mathrm{bdc})(\mathrm{dmf})[\mathrm{M}=\mathrm{Zn}, \mathrm{Cu}]$, Raman spectra of $\mathrm{Cu}(\mathrm{bdc})(\mathrm{ted})_{0.5}$ during hydration under 6 Torr, X-ray diffraction pattern of $\mathrm{Cu}(\mathrm{bdc})(\text { ted })_{0.5}$ during hydration under 6 Torr, X-ray diffraction patterns of $\mathrm{Cu}(\mathrm{bdc}) \cdot(\mathrm{dmf}), \mathrm{Zn}(\mathrm{bdc})(\mathrm{dmf})$ and MOF-2 structure, cyclic adsorption/desorption of water experiment, IR spectra of $\mathrm{D}_{2} \mathrm{O}$ adsorption into $\mathrm{M}(\mathrm{bdc})(\text { ted })_{0.5}[\mathrm{M}=\mathrm{Zn}$, $\mathrm{Ni}, \mathrm{Co}$ ] and integrated areas of stretching band in the region of $2736-1753 \mathrm{~cm}^{-1}$ as a function of vapor pressure.

\section{AUTHOR INFORMATION}

\section{Corresponding Author}

* Phone 1-972-883-5751; e-mail: chabal@utdallas.edu.

\section{ACKNOWLEDGMENT}

This work was supported in its totality by the Department of Energy, Basic Energy Sciences, division of Materials Sciences and Engineering (DOE grant No. DE-FG02-08ER46491).

\section{REFERENCES}

(7) Ward, M. D. Science.2003, 300, 1104-1105.

(1) Wu, H.; Gong, Q.; Olson, D. H.; Li, J. Chem. Rev. 2012, 112, $836-868$.

(2) Zhou, H. C.; Long, J. R.; Yaghi, O. M. Chem. Rev. 2012, 112, $673-674$.

(3) Ferey, G. Chem. Soc. Rev. 2008, 37, 191-214.

(4) Shekhah, O.; Wang, H.; Zacher, D.; Fischer, R. A.; Woll, C. Angew. Chem. Int. Ed. 2009, 48, 5038 -5041.

(5) Seo, J. S.; Whang, D.; Lee, H.; Jun, S. I.; Oh, J.; Jeon, Y. J.; Kim, K. Nature. 2000, 404, 982-986.

(6) Ferey, G.; Latroche, M.; Serre, C.; Loiseau, T.; Millange, F.; Percheron-Guegan, A. Chem. Commun. 2003, 2976-2977.

(8) Lin, X.; Jia, J.; Hubberstey, P.; Schroder, M.; Champness, N. R. CrystEngComm, 2007, 9, 438-448.

(9) Collins, D. J.; Zhou, H. C. J. Mater. Chem. 2007, 17, 31543160.

(10) Morris, R. E.; Wheatley, P. S. Angew. Chem. Int. Ed. 2008, 47, 4966-4981.

(11) Ma, S. Q.; Sun , D.; Simmons, J. M.; Collier , C. D.; Yuan , D.; Zhou, H. C. J. Am. Chem. Soc. 2008, 130, 1012-1016.

(12) M. Dinca.; Long, J. R. Angew. Chem. Int. Ed. 2008, 47, 67666779. 
(13) Horcajada, P.; Gref, R.; Baati, T.; Allan, P, K.; Maurin, G.;

Couvreur, P.; Ferey, G.; Morris, R. E.; Serre, C. Chem. Rev. 2012, $112(2), 1232-1268$.

(14) Lamberti, C.; Zecchina, A.; Groppo, E.; Bordiga, S. Chem. Soc. Rev. 2010, 39, 4951-5001.

(15) Sumida, K.; Rogow, D. L.; Mason, J. A.; McDonald, T. M.; Bloch, E. D.; Herm, Z. R.; Bae, T, H.; Long, J. R. Chem. Rev. 2012, 112(2), 724-781.

(16) Suh, M. P.; Park, H. J.; Prasad, T. K.; Lim, D. W. Chem. Rev. 2012, 112(2), 782-835.

(17) Li, Y.; Yang, R. T. Langmuir. 2007, 23, 12937-12944.

(18) Low, J. J.; Benin, A. I.; Jakubczak, P.; Abrahamian, J. F.; Faheem, S. A.; Willis, R. R. J. Am. Chem. Soc. 2009, 131, 1583415842.

(19) Saha, D.; Deng, S. J. Phys. Chem. Lett. 2010, 1, 73-78.

(20) Huang, L. M.; Wang, H. T.; Chen, J. X.; Wang, Z. B.; Sun, J. Y.; Zhao, D. Y.; Yan, Y. S. Microporous Mesoporous Mater. $2003,58,105-114$.

(21) Greathouse, J. A.; Allendorf, M. D. J. Am. Chem. Soc. 2006, $128,10678-10679$.

(22) Li, Y.; Yang, R. T. Langmuir, 2007, 23, 12937-12944.

(23) Han, S. S.; Choi, S. H.; van Duin, A. C. C. Chem. Commun. $2010,46,5713-5715$.

(24) Mori, W.; Inoue, F.; Yoshida, K.; Nakayama, H.; Takamizawa.; Kishita, M. Chem. Lett. 1997, 26, 1219-1220.

(25) Deakin, L.; Arif, A. M.; Miller, J. S. Inorg. Chem. 1999, 38, $5072-5077$.

(26) Seki, K. Chem. Commun. 2001, 30, 1496-1497.

(27) Seki, K.; Mori, W. J. Phys. Chem. B. 2002, 106, 1380-1385.

(28) Dybtsev, D. N.; Chun, H.; Kim, K. Angew. Chem. Int. Ed. 2004, 43, 5033-5036.
(29) Lee, J. Y.; Olson, D. H.; Pan, L.; Emge, T. J.; Li, J. Adv. Funct. Mater. 2007, 17, 1255-1262.

(30) Lee, J. Y.; Pan, L.; Huang, X. Y.; Emge, T. J.; Li, J. Adv. Func. Mater. 2011, 21, 993-998.

(31) Zhao, Y. G.; Wu, H. H.; Emge, T. J.; Gong, Q. H.; Nijem, N.; Chabal, Y. J.; Kong, L. Z.; Langreth, D. C.; Liu, H.; Zeng, H. P.; Li, J. Chem. Euro. J. 2011, 17, 5101-5109.

(32) Chun, H.; Dybtsev, D.; Kim, H.; Kim, K. Chem.-Eur. J. 2005, $11,3521-3529$.

(33) Vagin, S. I.; Ott, A. K.; Rieger, B. Chem. Eng. Technol. 2007, $79,767-780$.

(34) Chen, B. L.; Ma, S. Q.; Zapata, F.; Fronczek, F. R.; Lobkovsky, E. B.; Zhou, H. C. Inorg. Chem. 2007, 46, 1233-1236.

(35) Maniam, P.; Stock, N. Inorg. Chem. 2011, 50, 5085-5097.

(36) Kozlevcar, B.; Leban, I.; Petric, M.; Petricek, S.; Roubeau, O.; Reediik, J.; Segedin, P. Inorg. Chim. Acta. 2004, 357, 42204230.

(37) Benbellat, N.; Gavrilenko, K. S.; Gal, Y. L.; Cador, O.; Golhen, S.; Gouasmia, A.; Fabre, J. M.; Quahab, L. Inorg. Chem. $2006,45,10440-10442$.

(38) Ma, B. Q.; Mulfort, K. L.; Hupp, J. T. Inorg. Chem. 2005, 44, $4912-4914$.

(39) Burnett, B. J.; Barron, P. M.; Hu, C. H.; Choe, W. J. Am. Chem. Soc. 2011, 133, 9984-9987.

(40) Nijem, N.; Thissen, P.; Yao, Y.; Longo, R. C.; Roodenko, K.; Wu, H.; Zhao, Y.; Cho, K.; Li, J.; Langreth, D.; Chabal, Y. J. J. Am. Chem. Soc. 2011, 133, 12849-12957.

(41) Nijem, N.; Kong, L. Z.; Zhao, Y. G.; Wu, H.; Li, J.; Langreth, D. C.; Chabal, Y. J. J. Am. Chem. Soc. 2011, 133, 4782-4784.

(42) Nijem, N.; Veyan, J.-F.; Kong, L.; Wu, H.; Zhao, Y.; Li, J.; Langreth, D. C.; Chabal, Y. J. J. Am. Chem. Soc. 2010, 132, $14834-14848$ 
(43) Nijem, N.; Veyan, J.-F.; Kong, L.; Li, K.; Pramanik, S.; Zhao,Y.; Li, J.; Langreth, D.; Chabal, Y. J. J. Am. Chem. Soc. $2010,132,1654-1664$.

(44) Vitillo, J. G.; Regli, L.; Chavan, S.; Richiardi, G.; Spoto, G.; Dietzel, P. D. C.; Bordiga, S.; Zechina, A. J. Am. Chem. Soc. $2008,130,8386-8396$

(45) Vimont, A.; Goupil, J. M.; Lavalley, J. C.; Daturi, M.; Surble, S.; Serre, C.; Millange, F.; Ferey, G.; Audebrand, N. J. Am. Chem. Soc. 2006, 128, 3218-3227.

(46) Leclerc, H; Devic, T.; Devautour-Vinot, S.; Bazin, P.; Audebrand, N.; Ferey, G.; Daturi, M.; Vimont, A.; Clet, G. J. Phys. Chem. C. 2011, 115, 19828-19840.

(47) Prestipino, C.; Regli, L.; Vitillo, J. G.; Bonino, F.; Damin, A.; Lamberti, C.; Zecchina, A.; Solari, P. L.; Kongshaug, K. O.; Bordiga, S. Chem. Mater. 2006, 18, 1337-1346.

(48) Giannozzi, P.; Bonini, S. B., N.; Calandra, M.; Car, R.; Cavazzoni, C.; Ceresoli, D.; Chiarotti, G. L.; Cococcioni, M.; Dabo, I.; Dal Corso, A.; Fabris, S.; Fratesi, G.; de Gironcoli, S.; Gebauer, R.; Gerstmann, U.; Gougoussis, C.; Kokalj, A.; Lazzeri, M.; Martin-Samos, L.; Marzari, N.; Mauri, F.; Mazzarello, R.; Paolini, S.; Pasquarello, A.; Paulatto, L.; Sbraccia, C.; Scandolo, S.; Sclauzero, G.; Seitsonen, A. P.; Smogunov, A.; Umari, P.; Wentzcovitch, R. M. J. Phys.: Condens. Matter. $2009,21,395502$.

(49) Dion, M.; Rydberg, H.; Schroder, E.; Langreth, D. C.; Lundqvist, B. I. Phys. Rev. Lett. 2004, 92, 246401.

(50) Langreth, D. C.; Lundqvist, B. I.; Chakarova-Kack, S. D.; Cooper, V. R.; Dion, M.; Hyldgaard, P.; Kelkkanen, A.; Kleis, J.; Kong, L. Z.; Li, S.; Moses, P. G.; Murray, E.; Puzder, A.; Ryberg, H.; Schroder, E.; Thonhauser, T. J. Phys.: Condens. Matter. 2009, 21, 084203.

(51) Thonhauser, T.; Cooper, V. R.; Li, S.; Puzder, A.; Hyldgaard, P.; Langreth, D. C. Phys. Rev. B. 2007, 76, 125112.
(52) Kong, L. Z.; Cooper, V. R.; Nijem, N.; Li, K.; Li, J.; Chabal, Y. J.; Langreth, D. C. Phys. Rev. B. 2009, 79, 081407.

(53) Monkhorst, H. J.; Pack, J. D. Phys. Rev. B. 1976, 13, 51885192.

(54) Arenas, J. F.; Marcos, J. I. Spectrochim. Acta. Part. A 1979, 35, $355-363$

(55) Tripathi, G. N. R.; Sheng, S. J. J. Mol. Struct. 1979, 57, 2134.

(56) Tellez, C. A.; Hollauer, E.; Mondragon, M. A.; Castano, V. M. Spectrochim. Acta, Part A. 2001, 57, 993-1007.

(57) Marzocchi, M. P.; Sbrana, G.; Zerbi, G. J. Am. Chem. Soc. $1965,87,1429-1432$

(58) Deacon, G.B.; Phillips, R. J.; Coord. Chem. Rev. 1980, 33, $227-250$.

(59) Pajtasova, M.; Ondrusova, D.; Jona, E.; Mojumdar, S. C.; L' alikova, S.; Bazylakova, T.; Gregor, M. J. Therm. Anal. Calorim. $2010,100,769-777$.

(60) Zacher, D.; Yusenko, K.; Betard, A.; Meilikhov, M.; Ladnorg, T.; Shekhah, O.; Terfort, A.; Woll, C.; Fischer, R. A. Chem.Eur. J. 2011, 17, 1448- 1455.

(61) Valderrama-Negron, A. C.; Alves, W. A.; Cruz, A. S.; Rogero, S. O.; Silva, D. D. O. Inorg. Chim. Acta. 2011, 367, 85-92.

(62) Tafipolsky, M.; Amirjalayer, S.; Schmid, R. J. Phys. Chem. C. $2010,114,14402-14409$

(63) Rowsell, J. L. C.; Yaghi, O. M. J. Am. Chem. Soc. 2006, 128, $1304-1315$.

(64) Liang, Z.; Marshall, M.; Chaffee, A. L. Microporous Mesoporous Mater. 2010, 132, 305-310.

(65) Serre, C.; Bourrelly, S.; Vimont, A.; Ramsahye, N. A.; Maurin, G.; Llewellyn, P. L.; Daturi, M.; Filinchuk, Y.; Leynaud, O.; Barnes, P.; Ferey, G. Adv. Mater. 2007, 19, 2246-2251. 
(66) Carson, C. G.; Hardcastle, K.; Schwartz, J.; Liu, X.; Hoffmann, C.; Gerhardt, R. A.; Tannenbaum, R.; Eur. J. Inorg. Chem. 2009, 16, 2338-2343.

(67) Mathey, Y.; Greig, D. R.; Shriver, D. F. Inorg. Chem. 1982, 21, $3409-3413$

(68) Guzonas, D. A.; Irish, D. E. Can. J. Chem. 1988, 66, 1249. 1257.

(69) Guzonas, D. A.; Irish, D. E.; Atkinson, G. F. Langmuir, 1989, $5,787-796$

(70) Irish, D. E.; Guzonas, D. A.; Atkinson, G. F. Surf. Sci. 1985, $158,314-324$.

(71) Braga, M.; Larsson, S. J. Phys. Chem. 1992, 96, 9218-9224.

(72) Pasto, D. J.; Chipman, D. M.; Worman, J. J. J. Phys. Chem. 1982, 86, 3981- 3989.

(73) Chen, Y. F.; Lee, J. Y.; Babarao, R.; Li, J.; Jiang, J. W. J. Phys. Chem. C. 2010, 114, 6602- 6609 .

(74) Valenzano, L.; Civalleri, B.; Chavan, S.; Bordiga, S.; Nilsen, M. H.; Jakobsen, S.; Lillerud, K. P.; Lamberti, C. Chem. Ma ter. 2011, 23, 1700-1718.

(75) Stepanian S. G.; Reva, I. D.; Radchenko, E. D.; Sheina, G. G. Vib. Spectrosc. 1996, 11, 123-133.

(76) Wang, X.; Andrews, L. Inorg. Chem. 2005, 44, 9076-9083.

(77) Hadzi, D.; Sheppard, N. Proc. R. Soc. London. 1953, A216, $247-266$.

(78) Saha, D.; Deng, S.; J. Phys. Chem. Lett. 2010, 1, 73-78.

(79) Chen, Z.; Xiang, S.; Zhao, D.; Chen, B. Cryst. Growth. Des. $2009,9,5293-5296$.

(80) Li, H.; Eddaoudi, M.; Groy, T. L.; Yaghi, O. M.; J. Am. Chem. Soc. $1998,120,8571-8572$.

(81) Clausen, H. F.; Poulsen, R. D.; Bond, A. D.; Chevallier, M. A. S.; Iversen, B. B. J. Solid State Chem. 2005, 178, 3342-3351.

(82) Nalaparaju, A.; Babarao, R.; Zhao, X. S.; Jiang, J. W. ACS Nano $2009,3,2563-2572$.
(83) Crupi, V.; Longo, F.; Majolino, D.; Venuti, V. J. Phys.: Condens. Matter. 2006, 18, 3563-3580.

(84) Marechal, Y. The Hydrogen Bond and the Water Molecule: the Physics and Chemistry of Water, Aqueous and Bio media; Elsevier: Amsterdam, 2007.

(85) Grodzicki, A.; Piszczek, P.; J. Mol. Struct. 1998, 43, 141-147.

(86) Soptrajanov, B. J. Mol. Struct. 2000, 555, 21-30.

(87) Soptrajanov, B.; Stefov, V.; Kuzmanovski, I.; Jovanovski, G.; Lutz, H. D.; Engelen, B. J. Mol. Struct. 2002, 613, 7-14.

(88) Simpson, D. J.; Bredow, T.; Gerson, A. R. Theor. Chem. Acc. $2005,114,242-252$.

(89) Odelius, M. Phys. Rev. Lett. 1999, 82, 3919-3922.

(90) Meyer, B.; Marx, D.; Dulub, O.; Diebold, U.; Kunat, M.; Langenberg, D.; Woll, C. Ang. Chem., Int. Ed. 2004, 43, 66416645.

(91) Sillen, L. G.; Martell, A. E. Lange's Handbook; The Chemical Society: London, 1964.

(92) Surratt, G. T.; Kunz, A. B. Phys. Rev. Lett. 1978, 40, 347-350.

(93) McKay, J. M.; Henrich, V. E. Phys. Rev. B 1985, 32, 6764 6772.

(94) Kitakatsu, N.; Maurice, V.; Hinnen, C.; Marcus, P. Surf. Sci. $1998,407,36-58$

(95) Yu, N.; Zhang, W. B.; Wang, N.; Wang, Y. F.; Tang, B. Y. J. Phys. Chem. C. 2008, 112, 452-457.

(96) Simpson, D. J.; Bredow, T.; Gerson, A. R. Theor. Chem. Acc. $2005,114,242-252$

(97) Lide, D. R. CRC Handbook of Chemistry and Physics, 89th ed.; CRC Press: Boca Raton, FL, 2009

(98) Nakai, T.; Murakami, Y.; Sasaki, Y.; Fujiwara, I.; Tagashira, S. Anal. Sci. 2004, 20, 235-237.

(99) Irvine, H.; Williams, R. J. P. J. Chem. Soc. 1953, 3192-3210. 
Graphic for Table of Contents

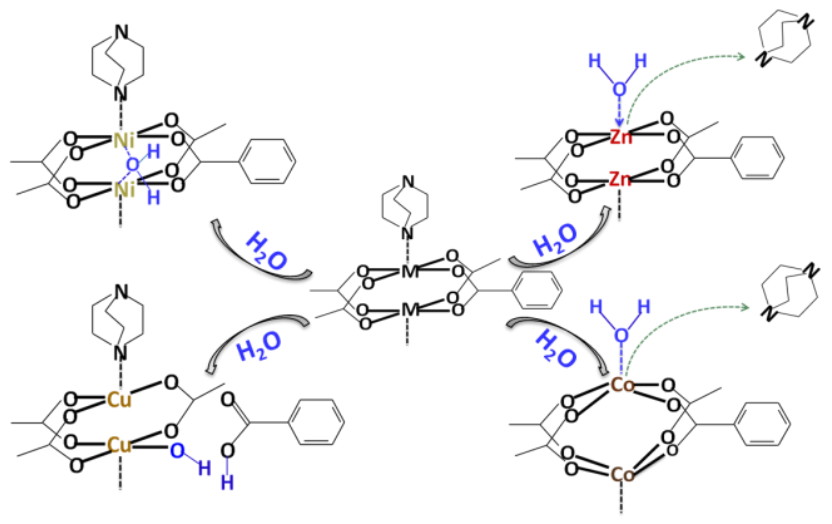

